Article

\title{
Mineralogical Study and Genetic Model of Efflorescent Salts and Crusts from Two Abandoned Tailings in the Taxco Mining District, Guerrero (Mexico)
}

\author{
Teresa Pi-Puig ${ }^{1,2, *}$, Jesús Solé ${ }^{1,2}$ and Adriana Gómez Cruz ${ }^{3}$ \\ 1 Instituto de Geología, Universidad Nacional Autónoma de México (UNAM), Cd. Universitaria, Coyoacán, \\ Mexico City 04510, Mexico; jsole@geologia.unam.mx \\ 2 Laboratorio Nacional de Geoquímica y Mineralogía (LANGEM), Universidad Nacional Autónoma de \\ México (UNAM), Cd. Universitaria, Coyoacán, Mexico City 04510, Mexico \\ 3 Posgrado en Ciencias de la Tierra, Universidad Nacional Autónoma de México (UNAM), Cd. Universitaria, \\ Coyoacán, Mexico City 04510, Mexico; adry.gc.6116@hotmail.com \\ * Correspondence: tpuig@geologia.unam.mx
}

Received: 31 July 2020; Accepted: 4 September 2020; Published: 1 October 2020

check for updates

\begin{abstract}
The mineralogy of surface crusts and efflorescent salts of two old abandoned tailings (Xochula and Remedios) of the mining district of Taxco, Guerrero, was studied by short-wave infrared spectroscopy (SWIR), X-ray diffraction (XRD), and scanning electron microscopy (SEM). The chemistry of the selected samples was studied with induced coupled plasma mass spectrometry (ICP-MS). Principal mineralogy is composed of hydrated sulfates of iron (di-trivalent), other less-soluble sulfates such as gypsum and jarosite, and oxides-hydroxides of iron, all of which are the result of the weathering of sulfides (mainly pyrite) accumulated in mining waste. Using quantitative X-ray diffraction (Rietveld method) and the spatial distribution of secondary minerals, two main zones (lateral and central) have been established in both tailings. The genetic model for their formation shows that the secondary iron minerals (sulfates, oxides, and hydroxides) in these deposits have been formed at least in three different stages, mainly by oxidation, dissolution, and precipitation processes in combination with dehydration and primary sulfides neutralization reactions. The chemical analyses of some salts confirm the presence of potentially toxic elements (PTE) in their structure and therefore indicate that the dissolution of the efflorescences in these deposits is a potential source of contamination during the wet season.
\end{abstract}

Keywords: hydrated sulfates; mining waste; X-ray diffraction; Rietveld method; SWIR

\section{Introduction}

The precipitation of sulfates in the form of efflorescent scabs or layers is a phenomenon that is characteristic of areas with acid drainage identified since antiquity [1] — because of its flower-like and concretion appearance-in the most superficial parts of the mining waste. They present a wide range of colorations (white, yellow, red, green, blue, etc.), and in general, there is a lack of vegetation in the area where they are located. Early civilizations established long ago the toxicity of the efflorescent salts [2].

In many Mexican mining districts, these efflorescences have been ignored, although the study of their mineralogy, their paragenetic sequence, and their spatial distribution is a critical aspect, since these minerals incorporate very toxic trace elements in their structures (in the substitution of iron and aluminum mainly) that can be easily released to water and soil by dissolution [3-5]. Its formation or dissolution modifies the hydrogen potential, as well as the content and transport of metals and sulfate 
from acid drainage waters. It is widely known that these sulfates are very susceptible to dissolve in rainy seasons or due to the action of surface waters releasing episodic pulses of highly acidic solutions. Then, they integrate toxic or contaminating elements into the drainage systems that can infiltrate the subsoil and impact the aquifers and the ecosystem in general [6-8].

The process of formation of these salts begins with the oxidation of sulfides such as pyrite in the presence of air or water, generating the necessary degree of acidity and the presence of cations. The rate of sulfide oxidation in tailings is high because a large volume of residues-characterized by a small crystal size and large reactive surface-is exposed to the action of the atmosphere. The efflorescent minerals precipitate by the evaporation of mine acid waters when the climate is warm and dry enough; they form a wide variety of crystal habits and aggregates, and their formation is determined mainly by the temperature, the degree of humidity, and the degree of oxidation on the surface of the mining waste [8-15]. Additionally, because the efflorescences are formed by fine material, they are susceptible to being transported during the rainy or windy periods $[16,17]$.

In general, the crystals of these metastable phases are very small and contain elements with diverse oxidation states. They can be difficult to identify because they form complex mixtures and their structure can be modified very easily by dehydration [18]. The identification of these sulfates provides information about the depositional environment and the interactions of mine tailings wastes with water and air, as they are very sensitive to environmental conditions $[6,8,17]$. The present study aims to review the presence of hazardous mineralogical phases in small abandoned mining residues which are very old, not delimited and labeled, and even with vegetation; they are frequently found in Mexico near mining areas.

The main goals of the present work are as follows: (a) to know the nature, proportion, and distribution of the sulfate and oxide minerals in the two studied areas, (b) to understand the degree of oxidation and evolution of efflorescences and, based on the above, (c) to be able to propose an evolutionary model about their formation and (d) evaluate their potential as a source of contamination.

\section{Historical Background and Description of the Study Area}

The Taxco Mining District (Guerrero State) is located at $1700 \mathrm{~m}$ of altitude on the northern of the Balsas-Mezcala basin on the flank of the Paleozoic Taxco-Zitácuaro outcrops [19].

The geology of the Taxco district is characterized by a marine section with Mesozoic schists in the basement, Lower Cretaceous limestones, and Upper Cretaceous shales, which are overlaid by continental conglomerates and Cenozoic volcanic rocks. The rocks are faulted and intruded by dikes and magmatic bodies of diverse age and composition (diorite, felsitic dikes, and diabases).

The Taxco ore deposits were described as polymetallic intermediate sulfidation epithermal deposits [19-21] with fluid mineralization temperatures between $200^{\circ} \mathrm{C}$ and $300^{\circ} \mathrm{C}$. The orebodies, with NW to NS orientation, are veins, stockworks, replacement mantos, and breccias, which are associated mainly with carbonates of the Mezcala and Morelos formations and less frequently with the Taxco Schist formation [22-24]. In distant parts, the skarn mineralization type is also present. Taxco is an important silver producer that is mainly associated with veins, but zinc and lead are also mined, mostly in mantos [24]. A significant amount of the mineralized bodies is constituted by galena (silver bearing), chalcopyrite, sphalerite, native silver, argentite, and silver secondary sulfosalts such as polybasite, proustite, and pyrargyrite. The gangue minerals include pyrite, pyrrhotite, stibnite, jamesonite, marcasite quartz, barite, fluorite, calcite, rhodochrosite, hematite, tremolite, epidote, and ilvaite $[19,23]$.

Since the 16th century, metal extraction has been carried out in the Taxco region and its surroundings, releasing a large amount of mineral waste that has been deposited in the environment over time [25]. There is little evidence of colonial waste, but by 1920, the first selective flotation profit plant had been installed by American Smelting and Refining Company [19], initiating the deposit of 
tailings through the Taxco district [23]. For a long time, the tailings were placed on the banks of rivers and other areas that over the years have been surrounded by human settlements [23,26].

In recent years, some research has been done on this type of deposit in the Taxco region, where the mining activity takes place [23-29]. However, to our knowledge, there are no published works that focus on the detailed mineralogical study of scabs and efflorescences of sulfates that form on the surface of the tailings because of their exposure to the weather.

The Xochula tailings (Figure 1) have approximate dimensions $85 \mathrm{~m}$ long by $25 \mathrm{~m}$ wide and a height of $3 \mathrm{~m}$. Only in the superficial central part is there vegetation that decays toward the ends of the deposit where crusts of violet to red coloration were identified. Xochula can be described as an oxidized tailings because its yellowish and brown colors are related with the presence of iron oxides and hydroxides or iron hydrated sulfates. At the NE of these tailings, there are small channels that seem to have been generated by the runoff of water coming from the highest parts. On the walls of these channels, white-colored salts with a fibrous habit and very irregular distribution were identified, which were probably formed by evaporation processes and forming thin crusts $(\leq 1 \mathrm{~cm})$ that only in certain points can be considered as true efflorescence (Figure 2).
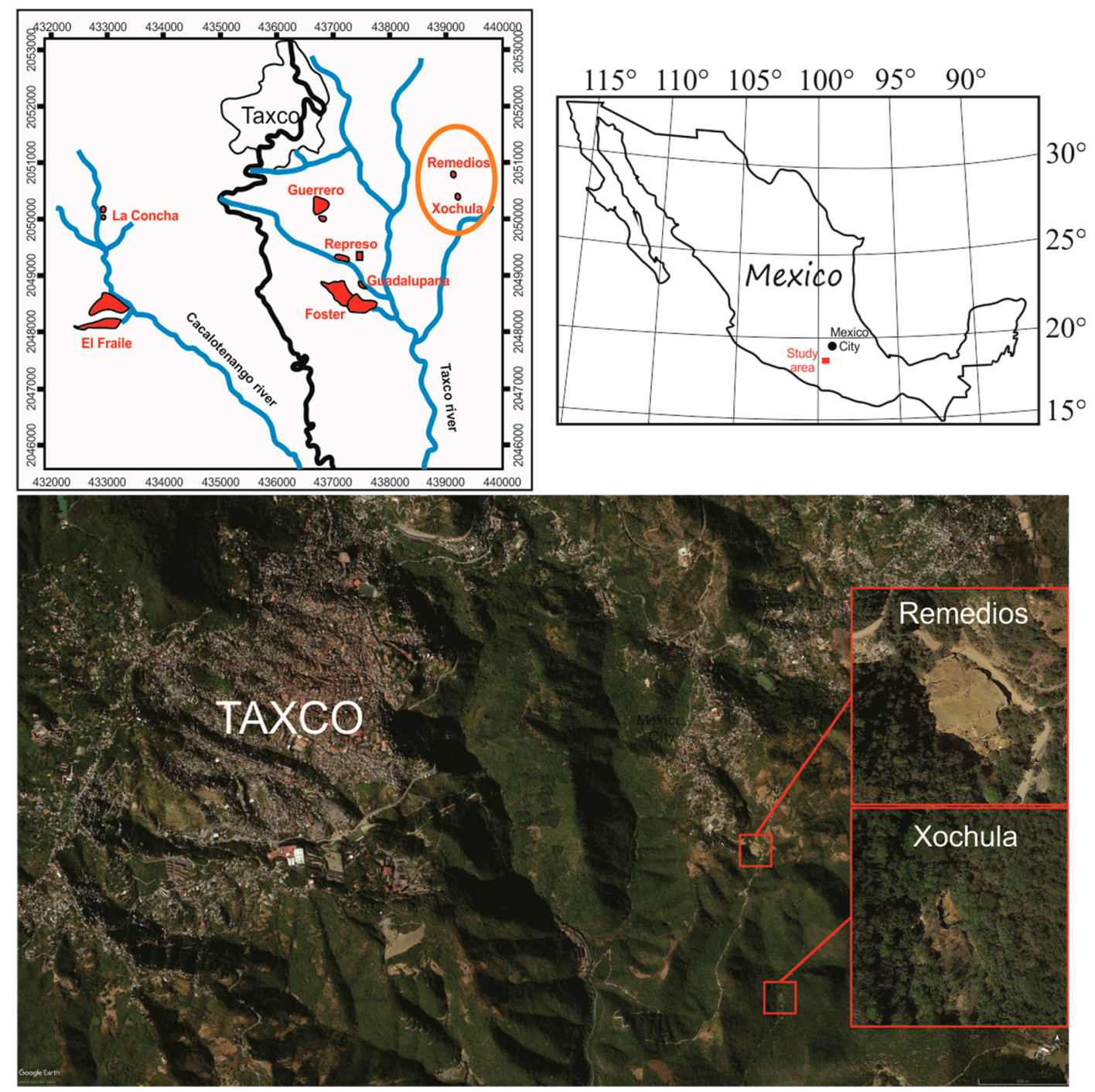

Figure 1. Location of the abandoned tailings studied in this work, produced by the mining activity in the Taxco district. Due to their size, the Fraile tailings are those that have been most studied $[23,27]$, but little work has been made up to this date to characterize the smaller tailings as Remedios and Xochula. Orange oval in the upper left-hand figure delimits the studied area. 

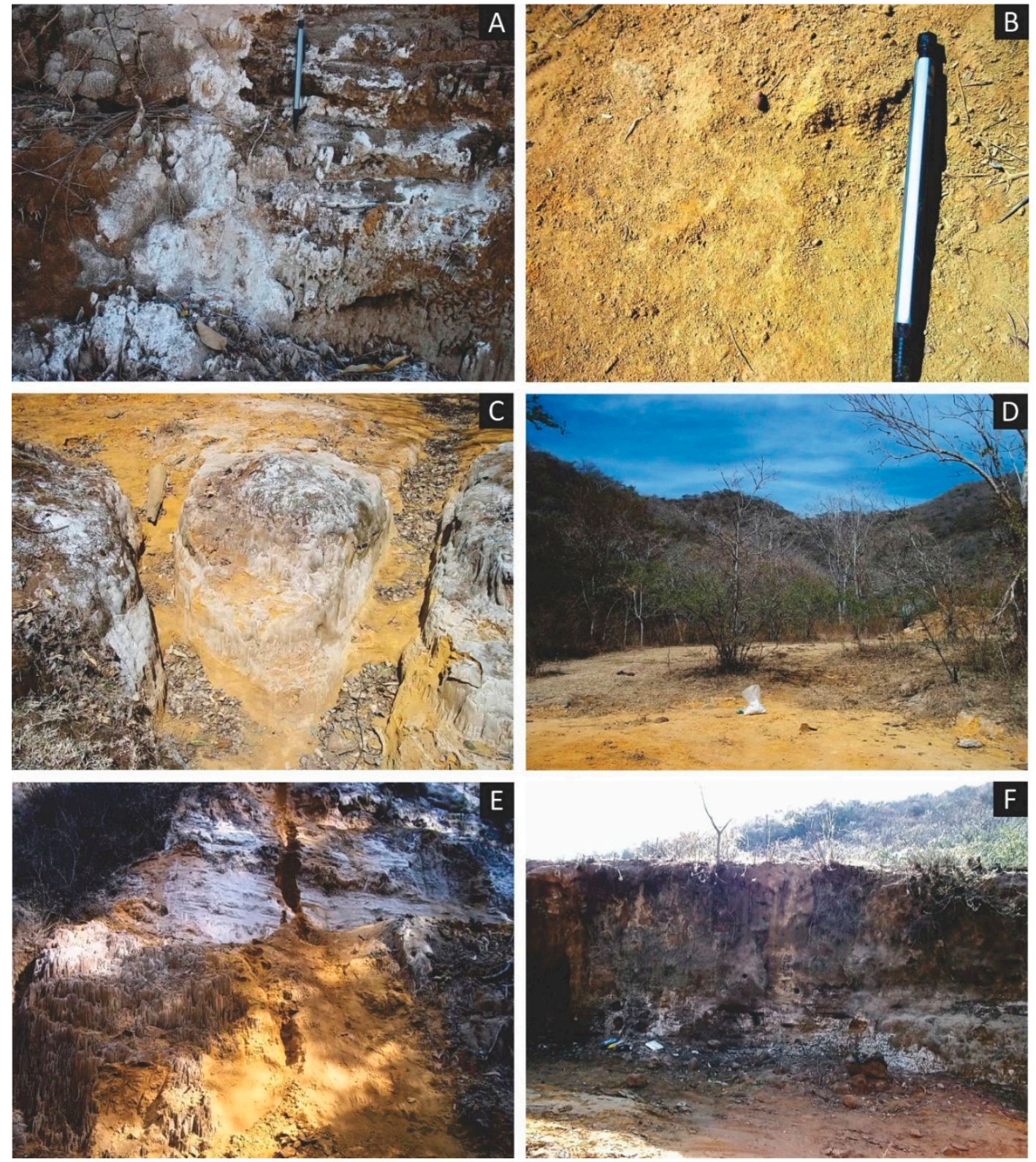

Figure 2. Field photographs of the Xochula tailings. (A) Appearance of the JH-38 sample with hydrated iron sulfates. (B) Sample JH-03 shows the field characteristics that generally present the materials without hydrated iron sulfates. (C) The gutters made at one end of the deposits are highlighted by the draining of the water from the surface toward the lower parts. The formation of structures of fibrous appearance in the walls of the channels. (D) Superficial view of the Xochula deposit, the presence of vegetation, and the formation of soils in some portions can be appreciated. (E,F) Views of two walls of the tailings highlight the presence of whitish colorations with efflorescent salts on both sides.

The Remedios tailings (Figure 1) have dimensions $55 \mathrm{~m}$ long by $45 \mathrm{~m}$ wide with a height from the ground of $10 \mathrm{~m}$. It is also oxidized tailings with low pyrite content, a stacked accumulated mining waste forming at least two independent terraces. Unlike the Xochula tailings deposit, it does not present vegetation, and there is no formation of soil on the surface. The colorations observed are very varied, although there is no pattern that defines their distribution. In this deposit, efflorescence is observed especially on the side walls, which are characterized by bright orange, yellowish, greenish, and whitish tones that are generally mixed. In the superficial part, different colorations also appear, although the efflorescence is less clear and with a more irregular distribution (Figure 3). 

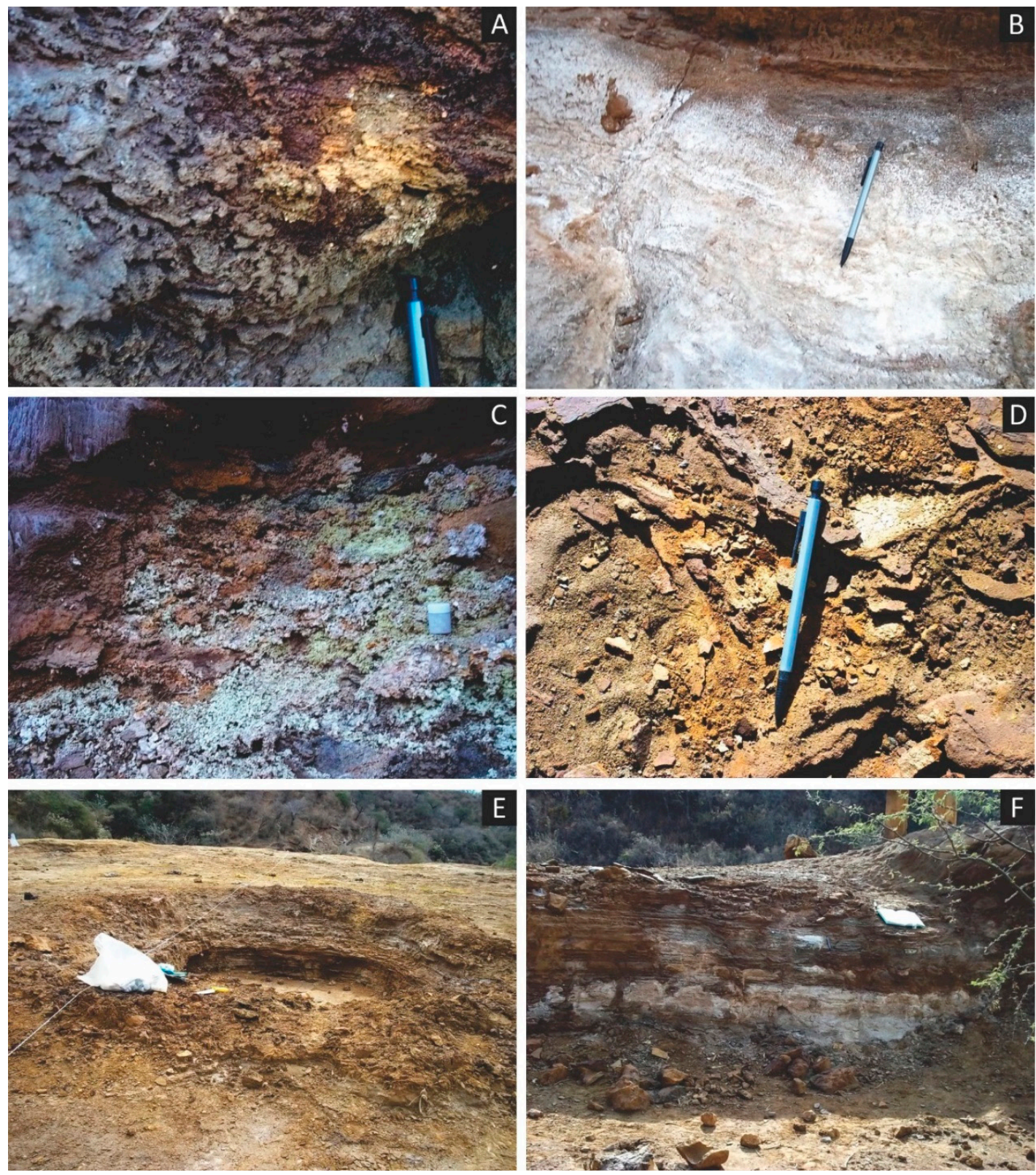

Figure 3. Field photographs of the Remedios tailings. (A-C) Photographs of samples containing iron hydrated sulfates; the macroscopic aspect of salts and efflorescences are highlighted. (D) Image of sample JT-33 located on the surface of the tailings shows the general macroscopic characteristics of materials that do not contain hydrated iron sulfates. $(\mathbf{E}, \mathbf{F})$ are panoramic views of the deposit both on the surface and on the wall.

\section{Materials and Methods}

\subsection{Sampling}

Prior to the collection of samples, the tailings were delimited with the help of images from Google Earth; a sampling square grid with a side length of $10 \mathrm{~m}$ was established. A total of 90 samples were taken, 41 corresponding to the Xochula tailings and 49 corresponding to the Remedios tailings. In addition to the $10 \mathrm{~m}$ grid sampling, changes in the colorations of the materials were also considered as sampling criteria. The samples chosen were mainly those with a fine-grained (sand and silt) and salt-like appearance. The samples were collected on the surface (up to $2 \mathrm{~cm}$ depth). The samples were collected during the dry season (May) with an aluminum spoon and stored in small airtight plastic 
bottles; then, they were stored in a dark room at $25^{\circ} \mathrm{C}$, where they remained until they were analyzed. The basic characteristics of each of the samples are detailed in Table 1 (Xochula tailings) and Table 2 (Remedios tailings). The sampling pattern was included as Figure S1.

Table 1. Physical description of samples from the superficial (JH-01 to JH-36) and lateral (JH-37 to JH-41) parts of Xochula Tailings.

\begin{tabular}{|c|c|c|c|}
\hline Sample & Origin & Coloration & Description \\
\hline JH-01 & Tailings & Yellowish orange & Very fine grain efflorescent salts \\
\hline $\mathrm{JH}-02$ & Tailings & Pale yellow & Soft crust without vegetation \\
\hline $\mathrm{JH}-03$ & Tailings & Yellowish orange & Material with fibrous texture \\
\hline $\mathrm{JH}-04$ & Soil & Yellowish brown and bluish & Fine grain with vegetation \\
\hline JH-05 & Tailings & Brownish-yellowish orange & Very fine grain without efflorescence \\
\hline JH-5-1 & Tailings and crust & Intense orange and violet red & Consolidated crust \\
\hline JH-06 & Soil & Orange brown & Fine grain with vegetation \\
\hline $\mathrm{JH}-07$ & Soil & Yellowish brown & Fine grain with vegetation \\
\hline $\mathrm{JH}-08$ & Soil & Brown & Consolidated material without vegetation \\
\hline JH-09 & Soil & Yellowish brown & Fine grain with vegetation \\
\hline $\mathrm{JH}-10$ & Soil & Yellowish brown & Fine grain with vegetation \\
\hline JH-11 & Soil & Brown & Fine grain with vegetation \\
\hline $\mathrm{JH}-12$ & Soil & Yellowish brown & Fine grain with vegetation \\
\hline $\mathrm{JH}-13$ & Soil & Yellowish reddish brown & Fine grain with vegetation \\
\hline $\mathrm{JH}-14$ & Soil & Orange brown & Fine grain with vegetation \\
\hline JH-15 & Soil & Yellowish brown & Fine grain with vegetation \\
\hline $\mathrm{JH}-16$ & Soil & Dark yellowish brown & Fine grain with vegetation \\
\hline $\mathrm{JH}-17$ & Tailings & Intense orange & Crust without vegetation \\
\hline JH-18 & Soil & Yellowish brown & Fine grain with vegetation \\
\hline JH-19 & Soil & Yellowish brown & Fine grain with vegetation \\
\hline $\mathrm{JH}-20$ & Tailings & Yellowish white & Very fine grain efflorescent salts \\
\hline JH-21 & Tailings & Bright yellow orange & Loose material without vegetation \\
\hline $\mathrm{JH}-22$ & Tailings & Dark Yellowish brown & Consolidated without vegetation \\
\hline $\mathrm{JH}-23$ & Soil & Light yellowish brown & Fine grain with vegetation \\
\hline $\mathrm{JH}-24$ & Soil & Yellowish brown & Fine grain with vegetation \\
\hline $\mathrm{JH}-25$ & Soil & Orange-reddish brown & Fine grain with vegetation \\
\hline JH-26 & Soil & Yellowish brown & Fine grain with vegetation \\
\hline $\mathrm{JH}-27$ & Soil & Yellowish brown & Fine grain with vegetation \\
\hline $\mathrm{JH}-28$ & Soil & Yellowish-orange brown & Fine grain with vegetation \\
\hline JH-29 & Soil & Yellowish brown & Fine grain with vegetation \\
\hline $\mathrm{JH}-30$ & Tailings & Intense orange & Fine grain without vegetation \\
\hline JH-31 & Tailings & Yellowish white & Very fine grain efflorescent salts \\
\hline $\mathrm{JH}-32$ & Tailings & Yellowish white & Very fine grain efflorescent salts \\
\hline $\mathrm{JH}-33$ & Tailings & Intense orange & Loose sandy material \\
\hline $\mathrm{JH}-34$ & Tailings & Intense orange and yellow & Loose sandy material \\
\hline JH-35 & Tailings & Intense orange & Loose sandy material \\
\hline $\mathrm{JH}-36$ & Tailings & Reddish violet and orange & Slightly hardened scab \\
\hline $\mathrm{JH}-37$ & Tailings & Yellowish white & Very fine grain efflorescent salts \\
\hline $\mathrm{JH}-38$ & Tailings & Whitish & Very fine grain efflorescent salts \\
\hline JH-39 & Tailings & White orange & Massive, fine-grained efflorescent salts \\
\hline $\mathrm{JH}-40$ & Tailings & Pink white & Very fine grain efflorescent salts \\
\hline $\mathrm{JH}-41$ & Tailings & Gray bluish lead & Consolidated material with fibrous texture \\
\hline
\end{tabular}

\subsection{Short-Wave Infrared Spectroscopy}

The analysis by short-wave infrared spectroscopy (SWIR) was performed for all 90 samples collected; the measurements were made with a portable Pro LabSpec spectrophotometer (Analytical Spectral Devices, Inc., Boulder, CO, USA). Before performing the measurement of the samples, a barite blank was measured to calibrate the equipment; this calibration was repeated every 5 measured samples. Before being analyzed, the samples were gently disintegrated with a spatula and placed in a small container. Each sample was measured in duplicate to verify the response of the spectrophotometer. 
At the end of the measurement, each sample was returned to their original container and stored in the room at $25^{\circ} \mathrm{C}$ for later analysis.

Table 2. Physical description of samples from the superficial (JT-01 to JT-47) and lateral (JT-03, JT-04, JT-05, JT-06, JT-16, JT-44, JT-45, JT-46, JT-48 and JT-49) parts of Remedios Tailings.

\begin{tabular}{|c|c|c|c|}
\hline Sample & Origin & Coloration & Description \\
\hline JT-01 & Tailings & Loose sandy material & Loose sandy material \\
\hline JT-02 & Tailings & Yellowish brown & Material with fibrous texture \\
\hline JT-07 & Tailings & Violet gray & Loose sandy material \\
\hline JT-08 & Tailings & Orange brown & Very fine grain efflorescent salts \\
\hline JT-09 & Tailings & Greenish yellow & Very fine grain efflorescent salts \\
\hline JT-10 & Tailings & Orange brown & Loose sandy material \\
\hline JT-11 & Tailings & Orange red & Loose sandy material \\
\hline JT-12 & Tailings & Intense orange and yellow & Loose sandy material \\
\hline JT-13 & Tailings & Yellowish orange & Weakly consolidated \\
\hline JT-14 & Tailings & Pink violet & Slightly hardened crust \\
\hline JT-15 & Tailings & Yellowish brown & Loose sandy material \\
\hline JT-17 & Tailings & Red brown & Slightly hardened scab \\
\hline JT-18 & Tailings & Red brown & Slightly hardened scab \\
\hline JT-19 & Tailings & Pink violet & Slightly hardened scab \\
\hline JT-20 & Tailings & Dark brown violet & Slightly hardened scab \\
\hline JT-21 & Tailings & Yellowish brown & Crust with disease cracks \\
\hline JT-22 & Tailings & Yellowish orange & Very fine grain efflorescent salts \\
\hline JT-23 & Tailings & Orange-red brown & Crust with disease cracks \\
\hline JT-24 & Tailings & Intense orange brown & Soft crust with efflorescence of fine particle size \\
\hline JT-25 & Tailings & Yellowish brown & Loose sandy material \\
\hline JT-26 & Tailings & Orange and greenish yellow & Loose sandy material \\
\hline JT-27 & Tailings & Amarillo greenish & Very fine grain efflorescent salts \\
\hline JT-28 & Tailings & Intense violet & Loose sandy material \\
\hline JT-29 & Tailings & Yellowish orange & Slightly hardened crust \\
\hline JT-30 & Tailings & Intense orange brown & Loose sandy material \\
\hline JT-31 & Tailings & Intense orange & Crust lightly hardened \\
\hline JT-32 & Tailings & Bright yellow & Loose sandy material \\
\hline JT-33 & Tailings & Bright orange & Very fine grain efflorescent salts \\
\hline JT-34 & Soil & Black & Crust lightly hardened \\
\hline JT-35 & Tailings & White orange & Very fine grain efflorescent salts \\
\hline JT-36 & Tailings & Bright violet & Very fine grain efflorescent salts \\
\hline JT-37 & Tailings & Reddish brown pink & Crust lightly hardened \\
\hline JT-38 & Tailings & Yellowish orange & Loose sandy material \\
\hline JT-39 & Tailings & Bright yellow & Stratified layers and crusts \\
\hline JT-40 & Tailings & Reddish brown & Loose sandy material \\
\hline JT-41 & Tailings & Yellowish orange & Stratified layers and crusts \\
\hline JT-42 & Tailings & Bright brown & Crust lightly hardened \\
\hline JT-43 & Tailings & Yellowish orange & Crust lightly hardened \\
\hline JT- 47 & Tailings & Orange white & Very fine grain and massive efflorescent salts \\
\hline JT-03 & Tailings & Bright orange and blue & Very fine grain and massive efflorescent salts \\
\hline JT-04 & Tailings & Whitish & Very fine grain and massive efflorescent salts \\
\hline JT-05 & Tailings & Bright greenish yellow & Very fine grain and massive efflorescent salts \\
\hline JT-06 & Tailings & Bright orange & Very fine grain and massive efflorescent salts \\
\hline JT-16 & Tailings & Yellowish white & Stratified layers and crusts \\
\hline JT-44 & Tailings & Yellowish white & Very fine grain and massive efflorescent salts \\
\hline JT-45 & Tailings & White & Very fine grain and massive efflorescent salts \\
\hline JT-46 & Tailings & Bright orange & Very fine grain and massive efflorescent salts \\
\hline JT-48 & Tailings & Bright brown & Weakly hardened scab \\
\hline JT-49 & Tailings & Bright white brown & Very fine grain and massive efflorescent salts \\
\hline
\end{tabular}

\subsection{X-ray Diffraction Analysis}

Bulk rock analysis was performed for all samples. Approximately two grams of each sample were taken, manually ground in an agate mortar, sieved to less than 45 microns, and loaded onto back side aluminum sample holders. The mineralogical analysis of the clay fraction was performed for 10 selected 
samples, which were gently disaggregated to avoid artificial grain size reduction [30]. Each sample was broken into small chips $(<2 \mathrm{~mm})$ using a porcelain crusher and subsequently dispersed in deionized water. The clay separation was done using the most non-aggressive method [31,32]. Grain size fractions of $<2 \mu \mathrm{m}$ were separated in distilled water according to Stoke's law with a Rotanta (Hettich) centrifuge operating at $6000 \mathrm{rpm}$ for $5 \mathrm{~min}$. From the $<2 \mu \mathrm{m}$ fractions, air-dried oriented preparations were obtained by pipetting some drops of the $\mathrm{Mg}$-saturated suspensions onto a glass slide, which was then dried at $30^{\circ} \mathrm{C}$ for a few hours [32]. Ethylene glycol solvation of the slides was achieved by exposing them to ethylene glycol vapor at $70^{\circ} \mathrm{C}$ for a minimum of $12 \mathrm{~h}$.

For X-ray diffraction analysis, an Empyrean diffractometer (Malvern Panalytical, Malvern, UK) equipped with a long fine tube (copper and cobalt), as well nickel and iron filters was used, operating at $40 \mathrm{~mA}$ and $45 \mathrm{kV}$, in a range of $4^{\circ}$ to $70^{\circ}$ (2 theta), with a step scan of $0.003^{\circ}(2 \theta)$ and $30 \mathrm{~s}$ of integration time. Phase identification and quantification by the Rietveld method was made using HighScore v4.5 software, making use of both International Center of Diffraction Database (ICDD) and Inorganic Crystal Structure Database (ICSD). Relevant data from the diffractometer used are shown in Table 3. The specimen-dependent parameters that were refined were the zero error, displacement error, polynomial fitting for the background with six coefficients, cell parameters, and atomic coordinates.

With the quantitative XRD results, a hierarchical clustering was performed with Statgraphics software (version 5.1) to recognize the genetic relation between the different mineral groups.

Table 3. Relevant data from the diffractometer used during measurement and Rietveld refinement.

\begin{tabular}{cccc}
\hline Parameter & Value & Parameter & Value \\
\hline Geometry & Bragg-Brentano & Divergence slit & $\frac{1}{2}^{\circ}$ \\
Goniometer radius & $240 \mathrm{~mm}$ & Incident antiscatter slit & $1^{\circ}$ \\
Radiation source & $\mathrm{CuK} \alpha$ and CoK $\alpha$ & Reflected antiscatter slit & $7.5^{\circ}$ \\
Generator & $45 \mathrm{kV}, 40 \mathrm{~mA}$ & Soller slits & $0.04 \mathrm{rad}$ \\
Tube & Long Fine Focus & Detector & Solid state (PIXcel3D) \\
Monochromator & None & Step size & $0.003^{\circ}(2 \theta)$ \\
Filter & Nickel (Cu) and Iron (Co) & Integration time & $30 \mathrm{~s}$ \\
Incident beam optics & Parallel mirror (Göbel) & Spinning & $15 \mathrm{rpm}$ \\
\hline
\end{tabular}

\subsection{Scanning Electron Microscopy}

A low vacuum scanning electron microscope Hitachi TM-1000 (Hitachi, Tokyo, Japan) was used. The preparation of the samples was not necessary; however, small fragments of efflorescence were selected, since the use of sprayed samples is not possible due to the vacuum system. The identification of the minerals observed was based on both the results of the Energy-Dispersive Spectroscopy (EDS) analysis and the observation of the morphologies and textures of the crystals and aggregates [12].

\subsection{Chemistry of Whole Rock and Trace Elements by Inductively Coupled Plasma}

In order to verify if the identified hydrated sulfates contain potentially toxic heavy elements (PTE), three samples of efflorescences from the Remedios tailings were analyzed by ICP-MS (inductively coupled plasma) at Activation Laboratories Ltd. (Ancaster, ON, Canada). A combination of packages Code 4B (lithium metaborate/tetraborate fusion ICP-OES whole rock) and Code 4B2 (trace element ICP-MS) was used. Fused samples were continuously mixed with a $5 \%$ nitric acid solution containing an internal standard until the sample was completely dissolved and analyzed with a Perkin Elmer Sciex ELAN ICP-MS. Three blanks and five controls (three before each sample group and two after) were analyzed with the samples. 


\section{Results}

\subsection{Short-Wave Infrared Spectroscopy}

The data obtained were corrected and plotted in Grapher (Golden Software, version 16, Golden, CO, USA), thus generating the spectra for each measured sample; it was plotted in the ranges of the near infrared (900 to $1400 \mathrm{~nm}$ ) and short-wave infrared (1400 to $2550 \mathrm{~nm}$ ). Mineral identification by this technique was based on the position of the absorption features of the representative spectrum of each group, as well as its general shape. In this study, a visual and numerical comparison of these characteristics was made with spectral libraries [33] and with spectra from [34,35]. The SWIR technique has been mainly used to discriminate samples with soluble sulfates from samples that do not contain

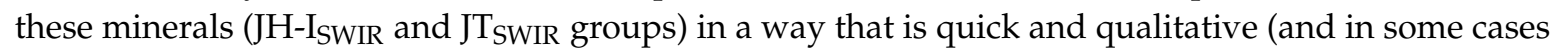
during field work). This discrimination is important because soluble sulfates are potentially more dangerous since they dissolve easily in rainy seasons.

To diagnose whether sulfates were present, the existence of a very distinct absorption band between 1700 and $1850 \mathrm{~nm}$ (approximately $1740 \mathrm{~nm}$ for gypsum and approximately $1850 \mathrm{~nm}$ for jarosite) was used $\left(v+\delta \mathrm{OH} / \mathrm{H}_{2} \mathrm{O}\right.$ and rotational fundamentals or $\delta S-\mathrm{O}$ overtones [35]). The bands located between 2100 and $2300 \mathrm{~nm}$ are related to the vibrations of the SO bonds, while those related to the metal-OH bond are found between 1480 and $2250 \mathrm{~nm}$ and can seldom be discriminated from the $\mathrm{SO}$ bands. The bands related with $\mathrm{H}_{2} \mathrm{O}+\mathrm{OH}$ bonds, those between 1440 and $1476 \mathrm{~nm}$, and those related with the $\mathrm{H}_{2} \mathrm{O}$ molecule alone are found between 1947 and $1969 \mathrm{~nm}$ [35].

Based on the absorption characteristics of the spectra obtained, and due to the great similarity that was found among many of them, a grouping was made and six clusters were established: three belonging to the Xochula tailings $\left(\mathrm{JH}-\mathrm{I}_{\mathrm{Swir}}, \mathrm{JH}-\mathrm{II}_{\text {Swir }}, \mathrm{JH}-\mathrm{III}_{\text {Swir }}\right.$; Figure 4 ) and three belonging to the Remedios one $\left(\mathrm{JT}-\mathrm{I}_{\mathrm{Swir}}, \mathrm{JT}-\mathrm{II}_{\mathrm{Swir}}, \mathrm{JT}-\mathrm{III}_{\mathrm{Swir}}\right.$; Figure 4). It is necessary to mention that there are small spectral variations within each group, since two samples with strictly equal absorption characteristics were not found. The first group was characterized in both tailings $\left(\mathrm{JH}-\mathrm{I}_{\text {Swir }}\right.$ and JT-I $\mathrm{I}_{\text {Swir }}$ ) by presenting a very flat spectrum in which only a small peak near $1850 \mathrm{~nm}$ stands out, which coincides with a characteristic band of jarosite mineral. This group is the most abundant and is characterized by the absence of soluble iron sulfates. Samples of the second group $\left(\mathrm{JH}-\mathrm{II}_{\mathrm{Swir}}\right.$ and JT-II $\left.\mathrm{Swir}_{\text {ir }}\right)$ were characterized by the presence of two important bands at $1850 \mathrm{~nm}$ and at $1400 \mathrm{~nm}\left(\mathrm{H}_{2} \mathrm{O}+\mathrm{OH}\right)$. For these spectra-also in the zone ranging from 2100 to $2300 \mathrm{~nm}$ - a single broad band appears, which corresponds mainly to the Fe-OH bond. Samples of the third group (JH-III $\mathrm{Swir}_{\text {, JT-III }}$ Swir $)$ were defined by the same absorption bands as the samples of the second group, but in the zone between 2100 and $2400 \mathrm{~nm}$, two different bands were discriminated, indicating the presence of two types of bonds between $\mathrm{OH}$ and metals.

A graphical comparison was also made of the spectra described above against the spectra of the main iron sulfates found in the literature $[34,35]$. From this comparison, it was possible to determine the presence of some characteristic absorption bands (bending and stretching, mainly of $\mathrm{H}_{2} \mathrm{O}, \mathrm{OH}$, $\mathrm{SO}_{4}$, and metal-OH) and relate them with the presence of rozenite, copiapite, jarosite, and hexahydrite (Figure 5). The SWIR equipment used is not state-of-the-art, but it can be used with confidence. Nevertheless, SWIR has not allowed us to discriminate the identity of all the soluble sulfates present in the samples, since these are generally complex mixtures with many phases and the absorption bands of the hydrated sulfates are often very similar to each other, as shown in Figure 4 . To discriminate the different sulfates and quantify their relative abundance, the infrared data were complemented with the X-ray diffraction data. 

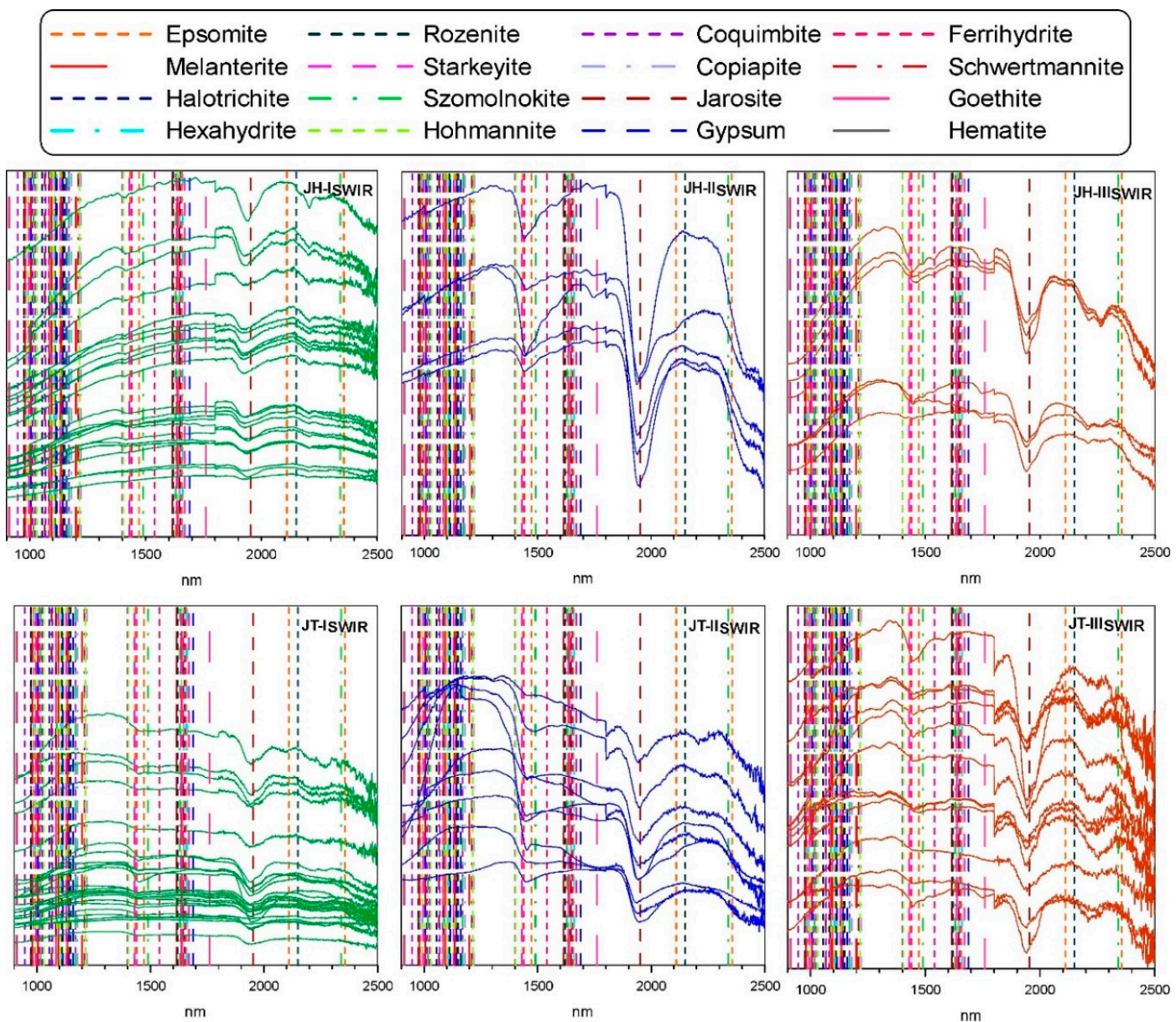

Figure 4. Groups established during the application of the analysis by infrared spectroscopy in the samples of the Xochula (JH) tailings and Remedios (JT) tailings. To facilitate the comparison with the minerals reported by other authors [33,35], the different bands (vertical lines) of the most important phases identified by X-ray diffraction were introduced. The first group of samples (green) is characterized by the presence of a very flat spectrum, in which only a small peak near $1850 \mathrm{~nm}$ stands out, coinciding with a characteristic band of jarosite mineral. This group is the most abundant and is also characterized by the absence of soluble iron sulfates. The second group (blue) is characterized by the presence of two important bands at $1850 \mathrm{~nm}$ and $1400 \mathrm{~nm}\left(\mathrm{H}_{2} \mathrm{O}+\mathrm{OH}\right)$. For these spectra, in the zone ranging from 2100 to $2300 \mathrm{~nm}$, a single broad band appears, which corresponds mainly to the $\mathrm{Fe}-\mathrm{OH}$ bond. The third group (brown) displays the same absorption bands as the samples of the second group, but it is characterized by the presence of two bands in the zone between 2100 and $2400 \mathrm{~nm}$, indicating the presence of two types of bonds between $\mathrm{OH}$ and metal.

\subsection{X-ray Diffraction}

Most of the minerals identified are of secondary (predominance of $\mathrm{Fe}^{2+}$ ) and tertiary (predominance of $\mathrm{Fe}^{3+}$ ) origin, and they correspond (Table 4) mainly to iron sulfates with different degrees of hydration, demonstrating that the main primary iron mineral accumulated in both mining residues was probably pyrite. The hydrated sulfates of iron predominate, but it is worth noting the presence, in low proportion, of hydrated magnesium sulfates with different hydration status ( 7 water molecules for epsomite, 6 water molecules for hexahydrite, 4 water molecules for starkeyite, and one water molecule for kieserite) in both tailings. For each of the tailings, a sample (JH2O and JT47) with gunningite was identified; this is a hydrated zinc and manganese sulfate. These data are congruent with the high zinc content of the samples analyzed by ICP-MS in this mining waste, as well as with the presence 
of sphalerite in the Taxco mineral deposit. Furthermore, a sample of Remedios tailings (JT47) with botryogen (magnesium and iron hydroxysulfate) was identified.
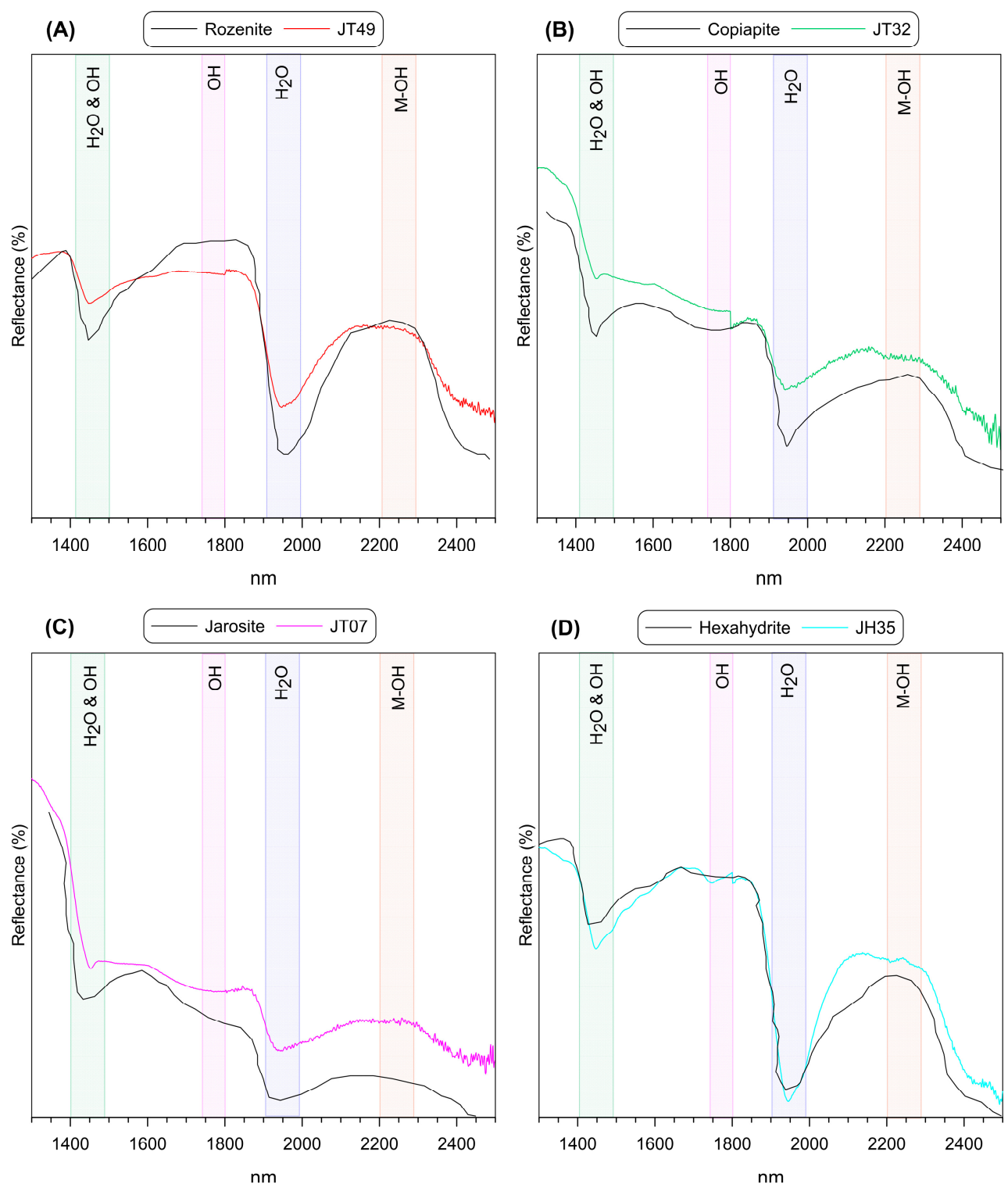

Figure 5. Characteristic short-wave infrared spectroscopy (SWIR) absorption spectra of some iron-bearing sulfates found at Taxco tailings. Reflectance spectra of (A) rozenite, (B) copiapite, (C) jarosite, and (D) hexahydrite, compared with digitalized literature spectra (Velasco et al., 2005; Cloutis et al., 2006). In general, only when the sample has more than $25 \%$ of the phase can a good correlation be observed.

\subsubsection{Xochula Tailings}

The primary minerals identified were quartz, feldspars, pyrite, fluorite, calcite, and clay minerals. For example, quartz was detected in 39 samples (17-82\%); feldspars, mainly plagioclase, were detected in 19 samples (4-15\%); pyrite was found in 13 samples (1-11\%); fluorite was found in six samples (2-8\%); carbonates were found in three samples (with a maximum of $7 \%$ ), and zeolites were found only in one sample (5\% in sample JH22). Phyllosilicates are more abundant than in the Remedios tailings and were identified in clay fraction $(<2 \mu \mathrm{m})$, mica-illite was identified in 27 samples $(2-27 \%)$, kaolinite was identified in 26 samples (3-17\%), smectite was identified in four samples (6-12\%), and chlorite was identified in only two samples, with a maximum ratio of $17 \%$ in sample JH14. These minerals are 
quite crystalline and were defined as primary minerals. The most important hydrated sulfate mineral in the Xochula tailings are coquimbite (in six samples with a maximum ratio of $30 \%$ in sample JH32), copiapite (in three samples in a range of $7 \%$ to $48 \%$ ), rozenite (in three samples with a range of $15 \%$ to $38 \%$ ), szomolnokite (in two samples with a maximum of $13 \%$ in sample JH38), and halotrichite (in two samples with a range of $5 \%$ to $16 \%$ ). Other minerals of this group are starkeyite (approximately $69 \%$ in sample JH20), hexahydrite (58\% in sample JH35), gunningite (9\% in sample JH20), and melanterite (4\% in sample JH04); all of them were only found in one sample each. As for insoluble sulfates, jarosite was identified in 18 samples (1\% to 19\%), alunite was identified in two samples (3\% to 5\%), and gypsum was identified in 22 samples ( $4 \%$ to $46 \%$ ). Regarding iron oxides and hydroxides, goethite was found in 10 samples ( $1 \%$ to $28 \%$ ), hematite was found in seven samples (2-10\%, always in a lower ratio than goethite), ferrihydrite was found in two samples (8 and 9\%), and schwertmannite was found only in one sample JH37 (8\%). Jarosite and gypsum were found both in samples rich in hydrated iron sulfates and in those that are characterized by the presence of oxides of this element, such as goethite and hematite. Table S1 shows the mineral phases identified and their relative abundance estimated by the Rietveld refinement method.

Table 4. Table with the non-primary minerals found in the studied efflorescences of Xochula (JH) and Remedios (JT) tailings.

\begin{tabular}{|c|c|c|c|c|c|c|c|}
\hline \multirow{2}{*}{$\begin{array}{c}\begin{array}{c}\text { Mineral } \\
\text { Name }\end{array} \\
\text { Botryogen }\end{array}$} & \multirow{2}{*}{$\frac{\text { Abbr. }}{\text { Bot }}$} & \multirow{2}{*}{$\begin{array}{c}\text { Chemical Formula } \\
\mathrm{MgFe}^{3+}\left(\mathrm{SO}_{4}\right)_{2}(\mathrm{OH}) \cdot 7\left(\mathrm{H}_{2} \mathrm{O}\right)\end{array}$} & \multirow{2}{*}{$\begin{array}{c}\text { Group } \\
\text { Iron and } \mathrm{Mg} \text { hydroxysulfate }\end{array}$} & \multirow{2}{*}{$\begin{array}{c}\text { XRD Pattern Ref. } \\
\text { ICSD } 980034682\end{array}$} & \multicolumn{3}{|c|}{ Characteristic XRD Peaks (Å) } \\
\hline & & & & & 6.36 & 8.96 & 5.52 \\
\hline Epsomite & Ep & $\mathrm{MgSO}_{4} \cdot 7\left(\mathrm{H}_{2} \mathrm{O}\right)$ & Hydrous Mg sulfate & ICSD 980029384 & 4.22 & 4.21 & 5.36 \\
\hline Hexahydrite & Hex & $\mathrm{MgSO}_{4} \cdot 6\left(\mathrm{H}_{2} \mathrm{O}\right)$ & Hydrous Mg sulfate & ICSD 980016546 & 4.36 & 5.45 & 4.03 \\
\hline Hohmannite & Hoh & $\mathrm{Fe}^{3+}{ }_{2}\left(\mathrm{SO}_{4}\right)_{2}(\mathrm{OH})_{2} \cdot 7\left(\mathrm{H}_{2} \mathrm{O}\right)$ & Iron hydroxysulfate & ICSD 980037328 & 7.96 & 8.73 & 10.42 \\
\hline Fibroferrite & $\mathrm{Fi}$ & $\mathrm{Fe}^{3+}\left(\mathrm{SO}_{4}\right)(\mathrm{OH}) \cdot 5\left(\mathrm{H}_{2} \mathrm{O}\right)$ & Iron hydroxysulfate & ICSD 980100721 & 12.08 & 4.07 & 3.45 \\
\hline Gunningite & Gun & $\left(\mathrm{Zn}, \mathrm{Mn}^{2+}\right) \mathrm{SO}_{4} \cdot \mathrm{H}_{2} \mathrm{O}$ & Hydrous $\mathrm{Zn}$ and Mn sulfate & ICSD 980071348 & 4.40 & 4.76 & 3.05 \\
\hline Rostite & Ros & $\mathrm{Al}\left(\mathrm{SO}_{4}\right)(\mathrm{OH}) \cdot 5 \mathrm{H}_{2} \mathrm{O}$ & Hydroxysulfate & ICDD 000421427 & 4.25 & 4.18 & 3.90 \\
\hline Rozenite & Roz & $\mathrm{FeSO}_{4} \cdot 4 \mathrm{H}_{2} \mathrm{O}$ & Hydrous Fe sulfate & ICSD 980023914 & 5.47 & 4.50 & 3.98 \\
\hline Starkeyite & Stk & $\mathrm{MgSO}_{4} \cdot 4\left(\mathrm{H}_{2} \mathrm{O}\right)$ & Hydrous Mg sulfate & ICDD 010721096 & 4.47 & 5.43 & 3.95 \\
\hline Szomolnokite & Szo & $\mathrm{Fe}^{2+} \mathrm{SO}_{4} \cdot\left(\mathrm{H}_{2} \mathrm{O}\right)$ & Hydrous Fe sulfate & ICSD 980027098 & 3.44 & 3.11 & 4.86 \\
\hline Copiapite & Cop & $\mathrm{Fe}^{2+} \mathrm{Fe}^{3+}{ }_{4}\left(\mathrm{SO}_{4}\right)_{6}(\mathrm{OH})_{2} 20\left(\mathrm{H}_{2} \mathrm{O}\right)$ & Hydroxysulfate & ICDD 000110395 & 10.5 & 6.87 & 3.43 \\
\hline Coquimbite & Coq & $\mathrm{Fe}^{3+}{ }_{2}\left(\mathrm{SO}_{4}\right)_{3} \cdot 9\left(\mathrm{H}_{2} \mathrm{O}\right)$ & Hydrous Fe sulfate & ICDD 010802836 & 8.27 & 9.45 & 3.36 \\
\hline Gypsum & Gy & $\mathrm{CaSO}_{4} \cdot 2 \mathrm{H}_{2} \mathrm{O}$ & Calcium sulfate dihydrate & ICSD 980161622 & 7.59 & 4.28 & 2.87 \\
\hline Ferrihydrite & Ferri & $\mathrm{Fe}^{3+}{ }_{2} \mathrm{O}_{3} \cdot 0.5\left(\mathrm{H}_{2} \mathrm{O}\right)$ & Hydrous ferric oxyhydroxide & ICSD 980056287 & 1.15 & 1.02 & 0.90 \\
\hline Goethite & Goe & $\mathrm{Fe}^{+3} \mathrm{O}(\mathrm{OH})$ & Iron oxyhydroxide & ICDD 010755065 & 4.18 & 2.45 & 3.88 \\
\hline Hematite & Hem & $\mathrm{Fe}_{2} \mathrm{O}_{3}$ & Iron oxide & ICDD 010715088 & 2.70 & 2.52 & 3.68 \\
\hline Schwertmann. & Schw & $\mathrm{Fe}^{3+}{ }_{16} \mathrm{O}_{16}(\mathrm{OH})_{12}\left(\mathrm{SO}_{4}\right)_{2}$ & Iron oxyhydroxysulfate & ICSD 980169971 & 2.55 & 3.39 & 4.86 \\
\hline
\end{tabular}

\subsubsection{Remedios Tailings}

The primary minerals identified were quartz, pyrite, anglesite (only in sample JT36), fluorite, zeolites, and clay minerals; they were found mainly in the samples impoverished in hydrous iron sulfates. These phases are distributed irregularly throughout the sampled area. For example, quartz was detected in almost all samples (5-82\%), pyrite was found only in seven samples in a proportion of $2 \%$ to $7 \%$, fluorite was found only in two samples $(6-7 \%)$, and carbonates and feldspars were not detected in the analyzed samples. Phyllosilicates were identified in clay fraction $(<2 \mu \mathrm{m})$ as mica-illite in 16 samples (1-16\%), kaolinite was identified in two samples (9-17\%), smectite was identified only as traces ( $<5 \%$ in several samples), and chlorite was identified in only three samples with a maximum percentage of $8 \%$. These minerals are always primary minerals. The most important hydrated sulfate mineral in the Remedios tailings is copiapite, which is present in 14 samples $(1 \%$ to $38 \%$ ). Other abundant minerals of this group are rozenite (in seven samples with percentages that vary from $2 \%$ to $33 \%$ ), coquimbite (in five samples with percentages that vary from $1 \%$ to $30 \%$ ), szomolnokite (in four samples with a maximum of $21 \%$ in sample JT06), and epsomite (in four samples with percentages from $2 \%$ to $24 \%$ ). Minerals such as hohmannite (45\% in sample JT46), 
metahohmannite (26\% in sample JT03), fibroferrite ( $3 \%$ in sample JT06), starkeyite ( $81 \%$ in sample JT04), and kieserite ( $20 \%$ in sample JT47) were identified only in one or two samples. Minerals of the alunite group such as hydronium or K-jarosite (identified in 42 samples with percentages that vary from $2 \%$ to $30 \%$ ), beudantite (identified in five samples with a maximum ratio of $5 \%$ in sample JT39), and plumbojarosite (identified in two samples with a maximum ratio of $11 \%$ in sample JT36) are present both in samples taken from the side walls of the deposit and in most of those taken from the surface. In the JT-04 sample, the presence of ferrihydrite (4\%) was confirmed. As a product of the oxidation and subsequent dehydration of primary sulfides [36], hematite was identified in 24 samples $(2-12 \%)$, and goethite was identified in 30 samples (2-33\%). Both minerals were found both in samples taken on the surface and in those taken on the side walls of the deposit. Gypsum, present in 46 samples, is a very ubiquitous mineral $(2-35 \%)$. Anhydrite was identified only as traces in the case of sample JT-46. Table S1 shows the mineral phases identified and their relative abundance estimated by the Rietveld refinement method [37].

\subsubsection{X-ray Diffraction General Grouping}

In order to compare the mineralogical results more easily and efficiently, seven genetic categories of minerals were established (primary (including gangue and ore minerals), phyllosilicates, secondary sulfates (with $\mathrm{Fe}^{2+}$ ), tertiary sulfates (with $\mathrm{Fe}^{3+}$ ), alunite group (alunite and all types of jarosite), iron oxides and hydroxides, and gypsum). Making these groupings was essential, since various minerals were discretely identified only in a few samples. Based on the XRD results and these seven mineralogical associations, three main groups of samples could be discriminated in each of the tailings (Figure 6).

Group I (JH-I $\mathrm{I}_{\mathrm{DR}}$ \& JT-I $\mathrm{I}_{\mathrm{DRX}}$ ): samples with primary minerals (mainly quartz) and phyllosilicates (mainly mica), gypsum, jarosite and, in a variable proportion, iron oxides and hydroxides. This group is characterized by the absence of soluble hydrated sulfates. Small amounts of pyrite were identified in some of these samples, which is more frequent in JH tailings (13 samples) than in JT ones ( 7 samples). Phyllosilicates are more abundant for JH samples, while oxides and hydroxides, gypsum, and jarosite are more abundant for JT samples (Figure 7).

Group II (JH-II $\mathrm{DRX}_{\mathrm{DX}}$ and JT-II $\left.\mathrm{DRX}\right)$ : samples with a predominance of secondary hydrated sulfates with reduced iron $\left(\mathrm{Fe}^{2+}\right)$. The predominant mineral of this group in both tailings is rozenite. Samples from that group may also contain jarosite, gypsum, quartz, or oxides and hydroxides in varying proportions.

Group III (JH-III $I_{\mathrm{DRX}}$ and JT-III $\left.\mathrm{DRX}\right)$ : samples with a predominance of hydrated tertiary iron sulfates (mainly coquimbite, as well as hohmannite and fibroferrite in specific samples), but which may also present a mixture of secondary and tertiary sulfates $\left(\mathrm{Fe}^{2+}+\mathrm{Fe}^{3+}\right)$ or minerals such as coquimbite, which has both oxidized and reduced iron. In the case of JH tailings, the predominant mineral of this type is coquimbite, while for JT samples, it is copiapite. Samples from that group may also contain quartz, jarosite, gypsum, iron oxides, and hydroxides in varying proportions.

The first group of samples established by XRD coincides for both mining tailings in more than $90 \%$ of the cases with group I of samples established by SWIR. The second and third groups established by XRD only partially coincide (63\%) with groups II and II established by SWIR. This is because the diffraction groups were established based on the presence of $\mathrm{Fe}^{2+}$ or $\mathrm{Fe}^{3+}$ in the minerals, but it is probable that groups II and III established by SWIR should have a more direct relationship with the structure of the different types of sulfate minerals [38]. However, since each sample is generally a complex mineral mixture, it has not been possible to dig deeper into this issue.

\subsection{Scanning Electron Microscopy}

By means of this technique, we were able to verify that the habit of iron-hydrated sulfates is mainly fibrous and that the crystals are generally of small size (clay and silt) (Figure 8). In many of the samples, the mixture of different hydrated phases was observed, evidencing that they were 
formed quickly by evaporation of the acid drainage mainly in the walls of the tailings, where the runoff processes are observed. Since many of the secondary minerals are iron sulfates with different oxidation and hydration states, it was not possible to discriminate among them by means of EDS measurements.
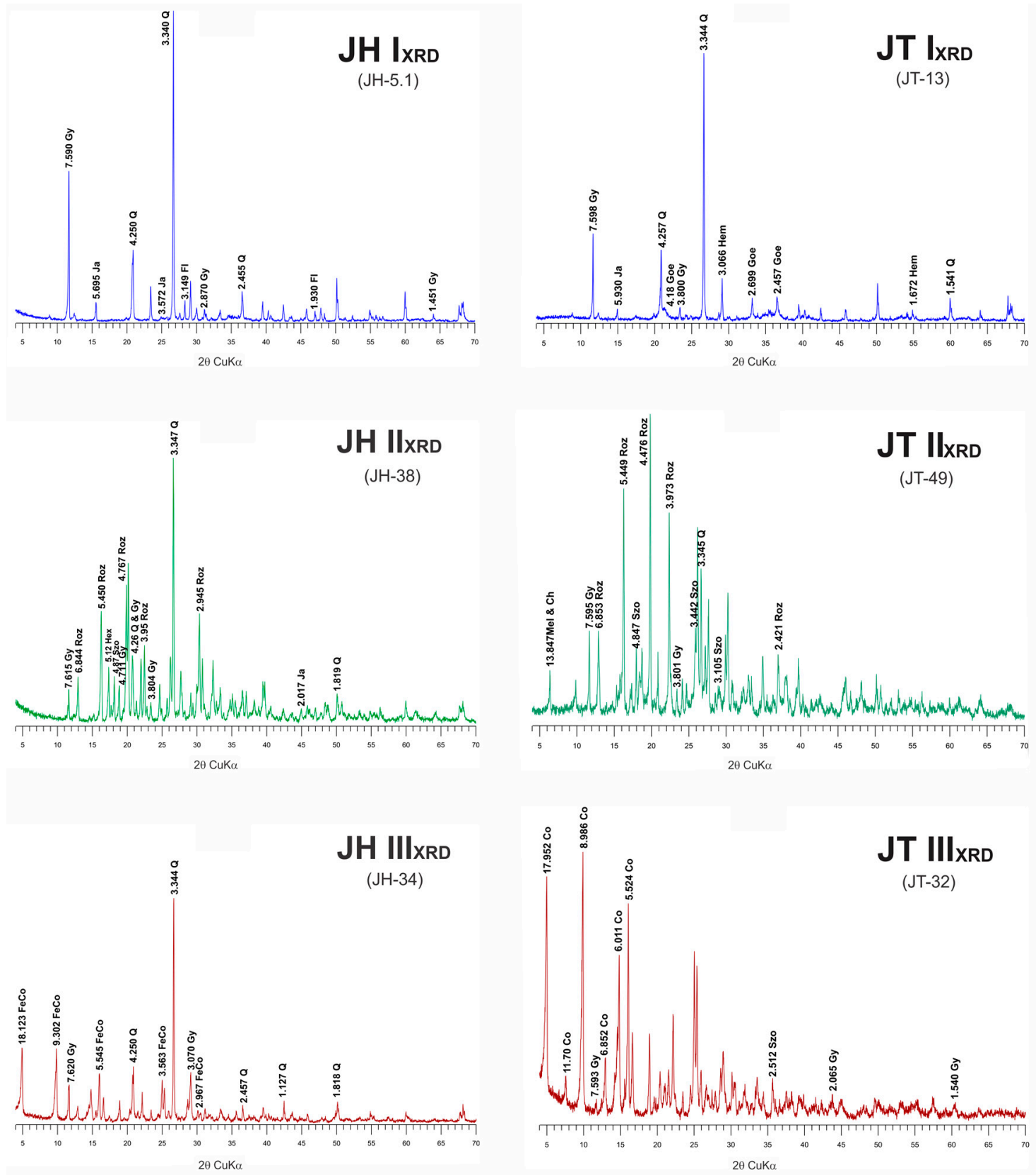

Figure 6. Representative XRD patterns from each of the three sample groups for Xochula (JH) tailings and Remedios (JT) tailings. The first group (blue) is characterized by the presence of primary minerals (mainly quartz) and phyllosilicates (mainly mica), gypsum, jarosite, and a variable proportion of iron oxides and hydroxides. The second group of samples (green) has a predominance of secondary hydrated sulfates with reduced iron $\left(\mathrm{Fe}^{2+}\right)$. Samples from that group may also contain jarosite, gypsum, iron, and/or quartz oxides and hydroxides in varying proportions. The third group of samples (brown) has a predominance of hydrated tertiary iron sulfates or a mixture of secondary and tertiary sulfates $\left(\mathrm{Fe}^{2+}+\mathrm{Fe}^{3+}\right)$. Samples from that group may also contain quartz, jarosite, gypsum, iron oxides, and hydroxides in varying proportions. Co: copiapite; Ch: chlorite; Hex: hexahydrite; FeCo: ferrocopiapite; Fl: fluorite; Goe: goethite; Gy: gypsum; Hem: hematite; Ja: jarosite; Q: quartz; Mel: melanterite; Roz: rozenite; Szo: szomolnokite. 


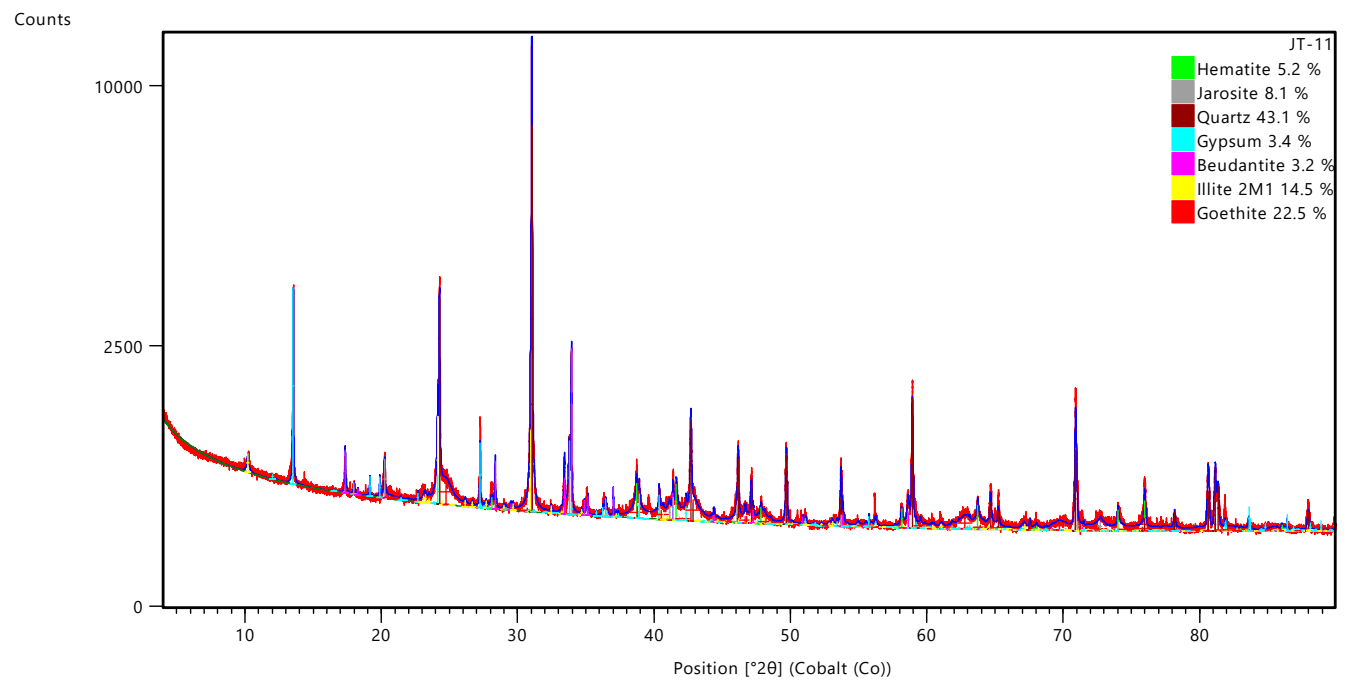

Figure 7. Example of quantification of crystalline phases using XRD and the Rietveld refinement method for sample JT11 (JT-I DRX).

\subsection{Geochemistry}

To verify if the hydrated sulfates identified contain in their structure potentially toxic heavy elements (PTE), three samples of efflorescences from the Remedios tailings were analyzed for major (Table 5) and trace elements (Table 6).

Regarding the major elements, all the samples analyzed have approximately the same amount of silica (21\% to $28 \%$ ), which coincides with the proportion of quartz (close to $20 \%$ ) that these samples present. The values of loss by ignition are very high ( $29 \%$ to $43 \%)$ in all samples, demonstrating that these are mainly constituted by sulfates (loss of $\mathrm{SO}_{3}$ ) with different degrees of hydration (loss of $\mathrm{H}_{2} \mathrm{O}$ ). The iron percentage is also very high and very close to $25 \% \mathrm{Fe}_{2} \mathrm{O}_{3}$ in the three samples. It can be related to the presence of iron oxides, hydrated iron sulfates, and traces of pyrite, the latter only for sample JT48. The $\mathrm{Al}_{2} \mathrm{O}_{3}$ content is always low and related to the presence of small amounts of phyllosilicates. The content of $\mathrm{CaO}(4 \%$ to $7 \%$ ) is related with the presence of gypsum in all samples (7\% to $18 \%$ by weight).

Table 5. Major element analysis from three samples of Remedios tailings. Concentrations in wt \%. All detection limits $0.01 \%$, except Mn, $0.001 \%$. LOI: loss on ignition.

\begin{tabular}{ccccccccccccc}
\hline Sample & $\mathbf{S i O}_{\mathbf{2}}$ & $\mathbf{A l}_{\mathbf{2}} \mathbf{O}_{\mathbf{3}}$ & $\mathbf{F e}_{\mathbf{2}} \mathbf{O}_{\mathbf{3}}(\mathbf{T})$ & $\mathbf{M n O}$ & $\mathbf{M g O}$ & $\mathbf{C a O}$ & $\mathbf{N a}_{\mathbf{2}} \mathbf{O}$ & $\mathbf{K}_{\mathbf{2}} \mathbf{O}$ & $\mathbf{T i O}_{\mathbf{2}}$ & $\mathbf{P}_{\mathbf{2}} \mathbf{O}_{\mathbf{5}}$ & LOI & Total \\
\hline JT-05 & 20.47 & 1.92 & 26.23 & 0.222 & 0.24 & 3.46 & 0.02 & 0.34 & 0.071 & 0.03 & 43.25 & 96.25 \\
JT-03 & 20.80 & 1.33 & 25.69 & 0.585 & 0.26 & 4.70 & 0.01 & 0.24 & 0.040 & 0.02 & 38.11 & 91.78 \\
JT-48 & 27.51 & 1.43 & 25.89 & 0.486 & 0.23 & 6.47 & 0.02 & 0.38 & 0.103 & 0.03 & 29.38 & 91.92 \\
\hline
\end{tabular}

Regarding the trace elements (Table 6), the samples are enriched in the following potentially toxic elements (PTE): $\mathrm{Cu}$ (850 to 980 ppm), Zn (2980 to 9000 ppm), As (453 to 569 ppm), Sn (573 to >1000 ppm), $\mathrm{Pb}$ (1260 to $4730 \mathrm{ppm}$ ), and, to a lesser extent, $\mathrm{Sb}$ (38 to $60 \mathrm{ppm}$ ) and W (34 to $59 \mathrm{ppm}$ ). Sample JT03 is the one that is more enriched in $\mathrm{Pb}$ and $\mathrm{Zn}$, while sample JT05 is the one with the highest content of As. The highest contents of $\mathrm{Cu}, \mathrm{Sn}, \mathrm{Sb}$, and $\mathrm{W}$ were found in sample JT48. $\mathrm{Zn}$ and $\mathrm{Cu}$ can be hosted in copiapites (soluble sulfate); on the other hand, $\mathrm{Pb}$ and As are hosted in minerals from the jarosite group (less soluble sulfate). By comparison of these results with those obtained in other abandoned tailings in Mexico—such as those of San Felipe [39] or those of Nacozari de García [40]—-the studied tailings of the Taxco mining district are those with the highest $\mathrm{Zn}$ and $\mathrm{Cu}$ enrichment; they are less enriched in As and $\mathrm{Pb}$ than those in San Felipe ( $>6000 \mathrm{ppm}$ As, $>8000 \mathrm{ppm} \mathrm{Pb}$ ) [39] but much more enriched in these elements than the tailings of Nacozari de García (29 ppm As, 39 ppm Pb) [40]. Based on the XRD 
mineralogical data, we can confirm that these potentially toxic elements are clearly associated with the hydrated iron sulfates. The concentrations of $\mathrm{Cu}, \mathrm{Zn}, \mathrm{As}, \mathrm{Pb}, \mathrm{Sn}$, and $\mathrm{Sb}$ exceed for all the samples the maximum permissible limits of toxicity for soils reported by the World Health Organization [41] and the regulations of the Secretary of Environment and Natural Resources (SEMARNAT) of the United States of Mexico [42].
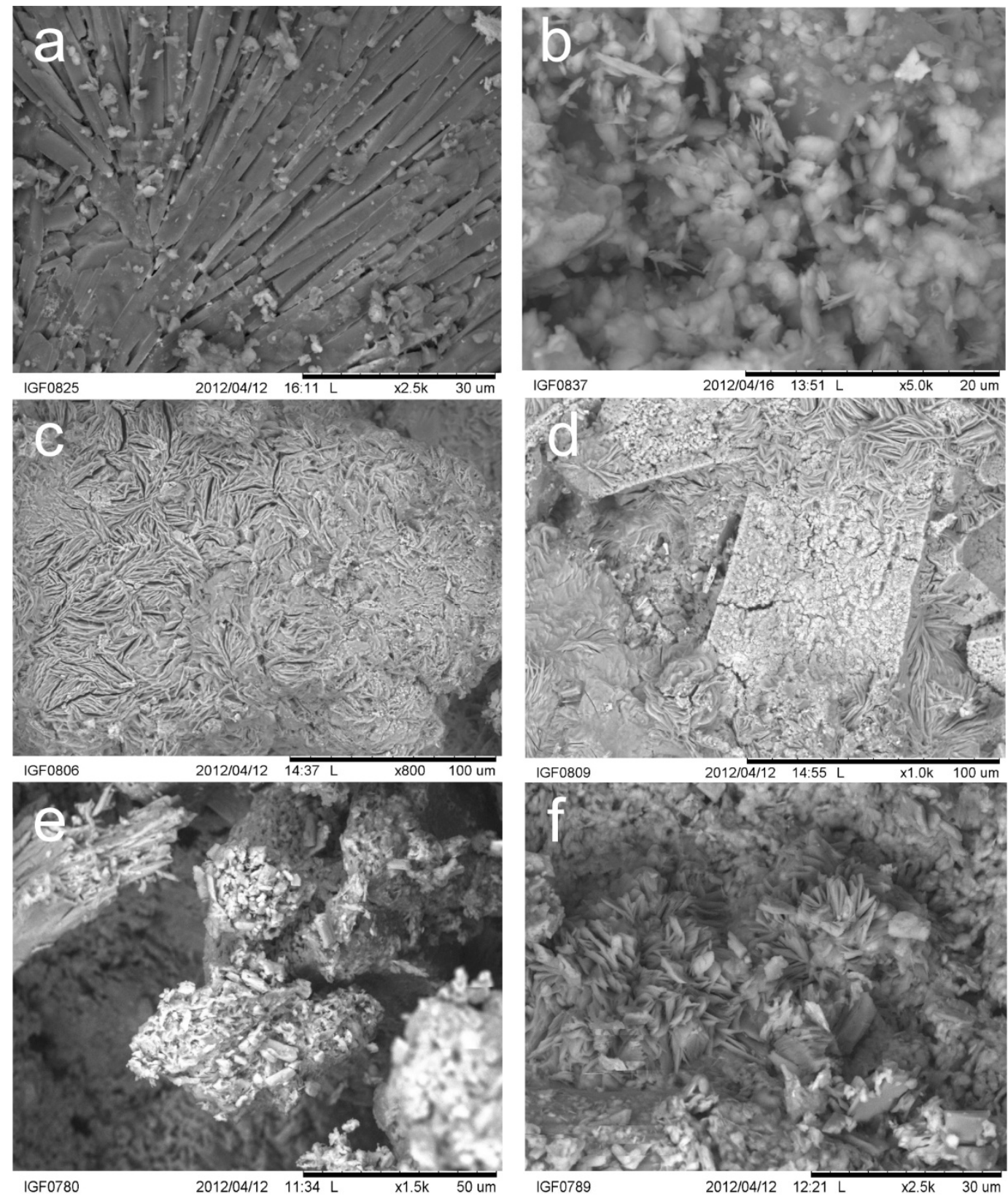

Figure 8. Microphotographs of samples with efflorescence. JH: Xochula; JT: Remedios. (a) Sample JH41, prismatic gypsum crystals; (b) Sample JH02, general aspect of the sample with different types of sulfates (mainly jarosite with anhedral crystals and tabular copiapite); (c) Sample JH48, tabular copiapite crystals; (d) Sample JH48, gypsum, jarosite, and clay minerals (central part), with tabular copiapite crystals at the external part; (e) Sample JT03, general appearance of the sample. It is observed that the sample is formed by an irregular mixture of different types of sulfates mixed with residues of the primary material; (f) Sample JT03, aggregate of copiapite crystals. In scale bar um $=\mu \mathrm{m}$. 
Table 6. Induced coupled plasma mass spectrometry (ICP-MS) analysis of some important trace elements from three samples of Remedios tailings. Concentrations in $\mu \mathrm{g} \mathrm{g}^{-1}$ (ppm). Detection limits: $\mathrm{Cu}$ (10), Zn (30), As (5), Sn (1), Sb (0.2), W (10), Pb (30). RBV: Regional background values [23]; NOM-141: NOM-141-SEMARNAT-2003 [42].

\begin{tabular}{cccccccc}
\hline Sample & Cu & Zn & As & Sn & Sb & W & Pb \\
\hline JT-05 & 850 & 2980 & 569 & 815 & 37.6 & 45.8 & 1260 \\
JT-03 & 880 & 9000 & 453 & 573 & 48.6 & 33.6 & 4730 \\
JT-48 & 980 & 6920 & 519 & $>1000$ & 59.5 & 58.8 & 2830 \\
RBV & 25 & 64 & 30 & - & 9.0 & - & 26 \\
NOM-141 & 100 & 100 & 20 & - & - & - & 100 \\
\hline
\end{tabular}

\section{Discussion}

\subsection{Mineral Zoning of the Mining Waste}

To establish the mineral zoning, the quantitative XRD results of the seven defined mineralogical groups (primary minerals, phyllosilicates, secondary hydrated sulfates, tertiary hydrated sulfates, alunite group, gypsum, and iron oxides and hydroxides) have been used as variables to (a) draw a contour map for Xochula (Figure 9) and Remedios Tailings (Figure 10) and (b) calculate a dendrogram using hierarchical clustering (Figure 11) that illustrates the statistic association between these groups in each of the tailings.

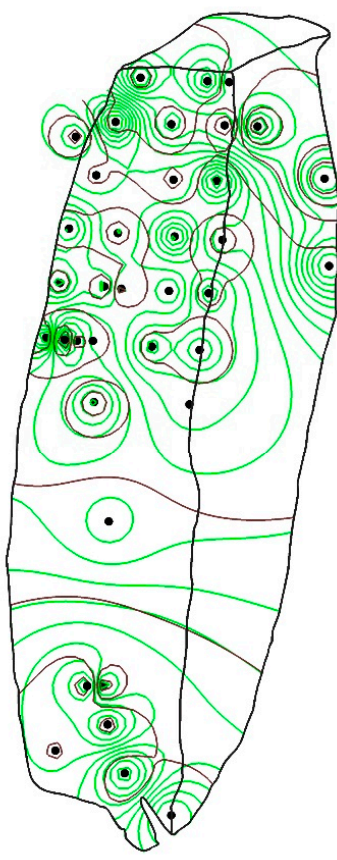

Primary minerals

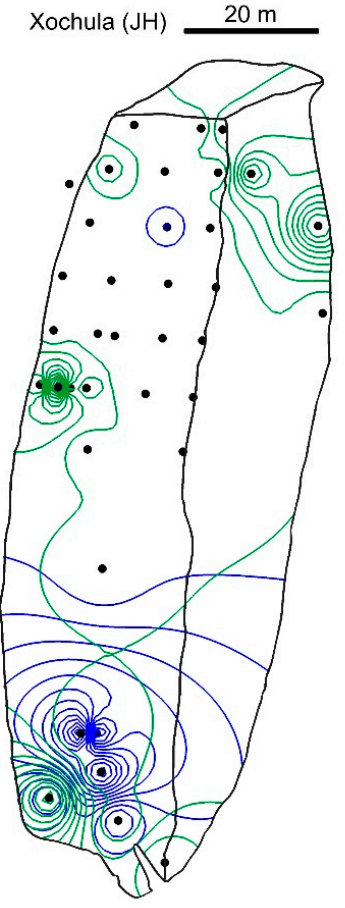

Secondary sulfates Tertiary sulfates

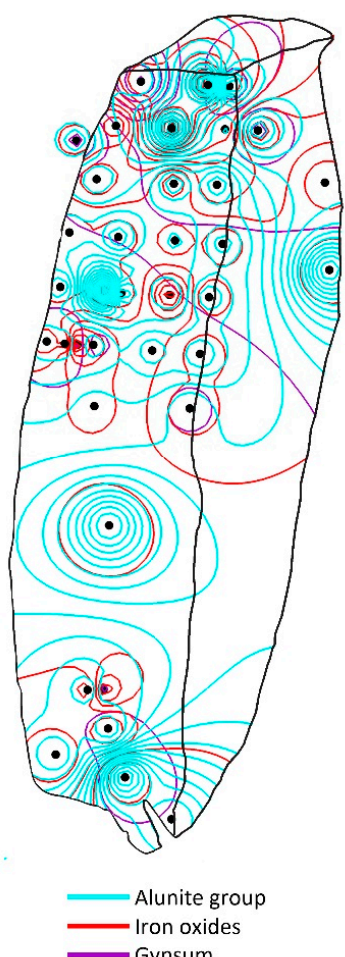

Figure 9. Contour map calculated from the quantitative data obtained using X-ray diffraction and the Rietveld method for Xochula (JH)) tailings. The groups considered are: primary minerals (pyrite, fluorite, calcite, and feldspars) in brown color, phyllosilicates (micas, smectites, kaolinite, chlorite) in light green color, secondary hydrated sulfates $\left(\mathrm{Fe}^{2+}\right)$ in dark green color, tertiary hydrated sulfates $\left(\mathrm{Fe}^{3+}\right)$ in blue color, alunite group minerals (mainly jarosite) in cyan color, gypsum in purple color, and iron oxides and hydroxides (schwertmannite, ferrihydrite, hematite, and goethite) in red color. The black line represents the outline of the tailings (superficial and lateral views). 

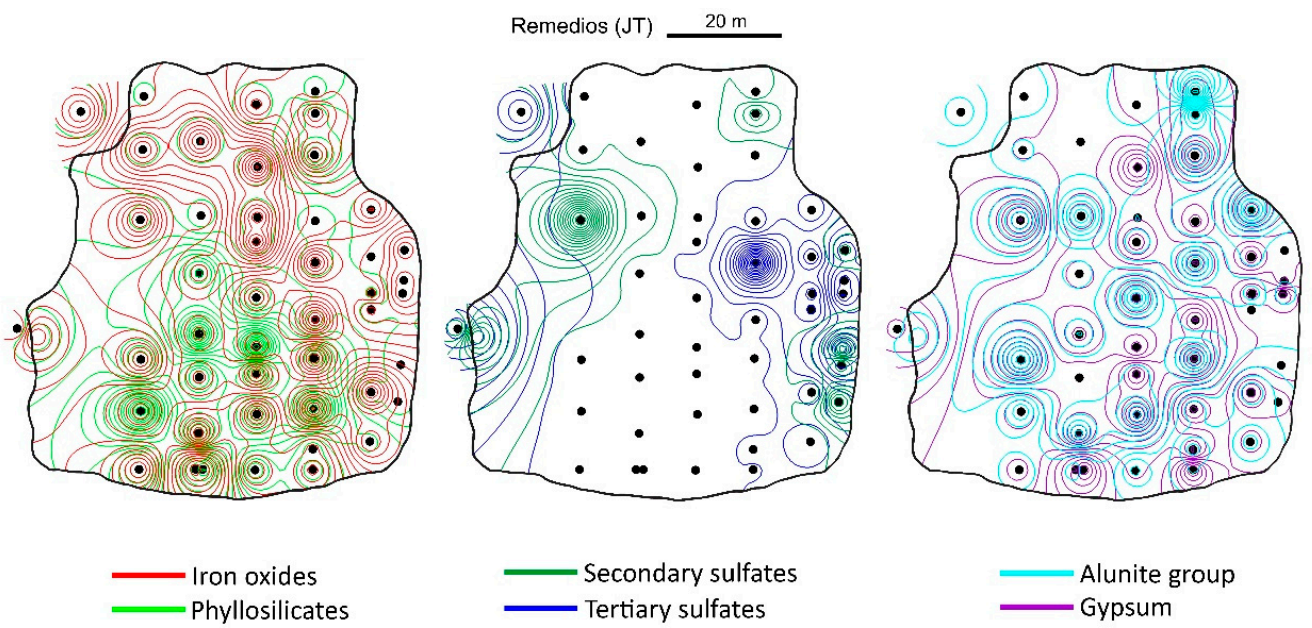

Figure 10. Contour map calculated from the quantitative data obtained using X-ray diffraction and the Rietveld method for Remedios (JT) tailings. The groups considered are: iron oxides and hydroxides (schwertmannite, ferrihydrite, hematite, and goethite) in red color, phyllosilicates (micas, smectites, kaolinite, and chlorite) in light green color, secondary hydrated sulfates $\left(\mathrm{Fe}^{2+}\right)$ in dark green color, tertiary hydrated sulfates $\left(\mathrm{Fe}^{3+}\right)$ in blue color, alunite group minerals (mainly jarosite) in cyan color, gypsum in purple color. The black line represents the outline of the tailings (superficial view).

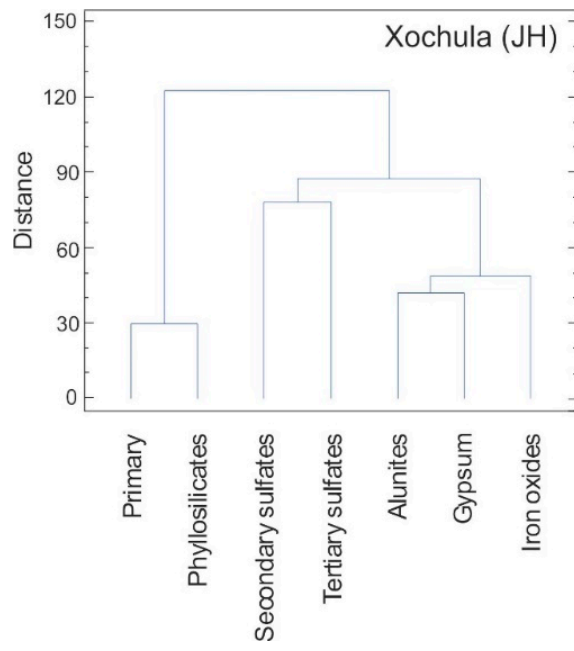

(A)



(B)

Figure 11. Dendrogram based on the quantitative $X$-ray diffraction data calculated with the Rietveld method. The groups considered are: primary minerals (pyrite, fluorite, calcite, and feldspars), secondary hydrated sulfates $\left(\mathrm{Fe}^{2+}\right)$, tertiary hydrated sulfates $\left(\mathrm{Fe}^{3+}\right)$, alunite group minerals (mainly jarosite), phyllosilicates (micas, smectites, kaolinite, and chlorite), gypsum, iron oxides and hydroxides (schwertmannite, ferrihydrite, hematite, and goethite). (A) Xochula (JH) and (B) Remedios (JT).

Based on these graphs, two different mineralogical zones have been distinguished for both tailings, which are the central, more horizontal area and the lateral or edge zone of the tailings. Secondary and tertiary hydrated soluble sulfates clearly predominate in the lateral zones and are practically non-existent in the central part of the tailings (Figures 9 and 10). Comparing the lateral areas of both tailings, tertiary (with $\mathrm{Fe}^{3+}$ ) hydrated soluble sulfates predominate in Remedios, while secondary ones $\left(\mathrm{Fe}^{2+}\right)$ are more abundant in the Remedios tailings. In both tailings, there is a good correlation between poorly soluble sulfates (jarosites and gypsum). However, while in the Xochula the distribution of alunite mineral group is similar to Remedios, the distribution of gypsum is more uneven. The iron oxides are distributed throughout all the Remedios tailings and correlate well with the distribution of primary minerals. In Xochula, the presence of iron oxides is much more reduced, and its distribution is 
directly related to the presence of jarosite (Figure 11A). The relationship between phyllosilicates and primary minerals is very clear in Xochula and less in Remedios, where the phyllosilicates are only found in the central part. These results are concordant with the color (yellowish to intense orange, violet, blue in the lateral part) distribution in the tailings.

The described zonation was governed mainly by the water runoff. In the areas through which the deposits drain, a greater presence of efflorescent salts was observed. In places where drainage channels were absent, few agglomerations of the efflorescent salts were observed. Runoff water infiltrates from the surface to the internal part and the sides of the tailings, precipitating by evaporation many of the elements that it carries in solution. The formation of the efflorescence occurs when the water saturated in different elements evaporates, depositing sulfates in the lower and lateral parts of the deposit. In the superficial part of the waste deposits, secondary minerals were mainly non-soluble sulfates such as gypsum and jarosite, as well as more evolved minerals such as iron oxides.

\subsection{Comparison of the Xochula Tailings with the Remedios Tailings}

Xochula (JH samples) is an old tailing (probably more than 100 years old) with the development of soil and vegetation on its surface. Remedios (JT samples) is a younger and bigger deposit without evidence of vegetation or soil formation, which is characterized by a greater diversity and abundance of soluble hydrated sulfates. In the case of Xochula, the predominant tertiary hydrated sulfate (with $\mathrm{Fe}^{3+}$ ) mineral is coquimbite, while for Remedios (JT samples) it is copiapite. Both tailings have a lot of quartz, but other primary minerals such as potassium feldspar or small amounts of calcite were only identified in the Xochula tailings. Pyrite was identified in $13 \mathrm{JH}$ samples and only in seven JT samples. Phyllosilicates are also more abundant for JH samples, whereas oxides and hydroxides, gypsum, and jarosite are at a higher abundance in JT samples. The presence of these clays on the surface of the tailings is related with the settlement of the soil and vegetation.

Almost all the identified sulfates are of iron, indicating that the tailings were originally deposits of residual pyrite. Being ancient accumulations and based on the obtained mineralogical results, it is interpreted that both have undergone several alteration cycles over the time that they have been exposed to weathering. The mineralogical evolution in both tailings is quite similar and can be classified as advanced. However, the irregular distribution of non-oxidized pyrite in tailings as old as these can only be related to waste dumping in more recent times (different episodes). The great abundance of gypsum without residues of calcite in the Remedios tailings could be an indication of the use of carbonates as a remediation mechanism in this bigger deposit.

\subsection{Genetic Model}

Different authors $[3,9,10,36]$ have demonstrated that the first hydrated iron sulfate that is formed during the pyrite alteration sequence is melanterite $\left[\mathrm{FeSO}_{4} \cdot 7\left(\mathrm{H}_{2} \mathrm{O}\right)\right]$, and that the process that allows its formation is evaporation. In the case of the tailings studied in Taxco, this mineral was found only in two (JT03, JH04) of all analyzed samples, which was attributed to the fact that melanterite is a mineral highly sensitive to changes in humidity and temperature, which means it could have been transformed easily to another phase. The blue-green colorations observed in the field (Table 1) suggest the presence of this mineral. From the melanterite, other iron (divalent) sulfates were formed by a dehydration process, such as rozenite $\left[\mathrm{FeSO}_{4} \cdot 4\left(\mathrm{H}_{2} \mathrm{O}\right)\right]$, which was present in the samples JH37, JH38, JH39, JT04, JT16, JT20, JT35, JT44, JT46, JT47 and JT49 and szomolnokite $\left[\mathrm{FeSO}_{4} \cdot \mathrm{H}_{2} \mathrm{O}\right]$, which is a mineral that was found in samples JH38, JH39, JT03, JT06, JT47, and JT49. It is known that rozenite precipitates are associated with very acidic $(\mathrm{pH} \approx 1)$ drainage waters [33]. Once the szomolnokite had been formed, the oxidation process began, and the dehydration continued to form di-trivalent iron sulfates, such as copiapite $\left[\mathrm{Fe}^{2+} \mathrm{Fe}^{3+}{ }_{4}\left(\mathrm{SO}_{4}\right)_{6}(\mathrm{OH})_{2} \cdot 20\left(\mathrm{H}_{2} \mathrm{O}\right)\right]$ (14 samples of JT and three samples of $\mathrm{JH}$ ) and coquimbite $\left[\mathrm{Fe}_{2-\mathrm{x}} \mathrm{Al}_{\mathrm{x}}\left(\mathrm{SO}_{4}\right)_{3} \cdot 9\left(\mathrm{H}_{2} \mathrm{O}\right), \mathrm{x} \sim 0.5\right]$, which were found in 11 samples (JT09, JT26, JT28, JT32, JT39, JH01, JH05, JH08, JH32, JH34, and JH37). It is known that ferrocopiapite precipitates from extremely $\mathrm{Fe}^{3+}$-rich solutions [43]. 
In many of the samples, these minerals originated by oxidation were mixed with other phases formed by dehydration; this mixture of processes acting on the same sample gives rise to the mineralogical variability that was identified. In a more evolved stage, schwertmannite $\left[\left(\mathrm{Fe}_{8} \mathrm{O}_{8}(\mathrm{OH})_{6}\left(\mathrm{SO}_{4}\right) \cdot \mathrm{n}\left(\mathrm{H}_{2} \mathrm{O}\right)\right]\right.$ was formed by the rapid oxidation of $\mathrm{Fe}^{2+}$ in acidic conditions [36]. This mineral was only identified in sample JH37, but due to its low crystallinity, it could also be present in other samples. It would be necessary to use other techniques such as Raman or X-ray absorption spectroscopy $[44,45]$ to confirm its identification.

Iron oxides and hydroxides identified during the study were ferrihydrite, goethite, and hematite. These minerals can be formed by the oxidation and hydrolysis of primary sulfides, especially pyrite. During the iron oxidation processes, the first phase that was precipitated by hydrolysis was ferrihydrite, but since it is a metastable material, it later changed to goethite or hematite. Another possible option for the formation of ferrihydrite in the studied area is through the dissolution-oxidation of hydrated sulfates such as rozenite, szomolnokite, copiapite, and coquimbite. Once formed, ferrihydrite can be decomposed by dehydration to form goethite. If dehydration continues, hematite is formed. Ferrihydrite was only found in three samples (JT04, JH22, and JH36), which indicates that if it was formed at an earlier stage, it may have already transformed to form goethite or hematite. This mineral was not found mixed with other oxides. Hematite and goethite were observed as mixed phases in many samples.

Oxides were formed by the two aforementioned processes: the uninterrupted process of alteration of pyrite (during the wet or rainy season), and the dissolution-dehydration of ferrous sulfates, which would have been formed prior to the interruption of the oxidation process of pyrite during the dry period. Their possible formation by bacterial activity was not demonstrated in this work, but it is important to mention that, as presented by [36] in his training model, the biological environment plays a decisive role in their formation. For example, the bacterium Acidithiobacillus ferrooxidans is an acidophilic bacterium with a physiology based on the fixation of carbon from atmospheric $\mathrm{CO}_{2}$, obtaining its energy from the oxidation of iron.

Jarosite is represented in half of the Xochula tailings samples and in almost all the samples from Remedios tailings (the exception of six samples). Oxides were probably formed from the alteration of the jarosite; therefore, associations of jarosite-goethite-hematite were observed in several samples.

The stability of the jarosite depends on the $\mathrm{pH}$; with the increase of $\mathrm{pH}$ values, jarosite tends to transform into goethite. If the sulfuric acid generated by the primary oxidation of pyrite is not neutralized, the $\mathrm{pH}$ decreases; under these conditions, jarosite is formed from ferric iron oxides. An important role in the production of jarosite during the oxidation of ferrous iron is the bacterial activity of Acidithiobacillus ferrooxidans [46]. Based on this, three evolutionary stages are proposed to explain the formation of these mining wastes (Figure 12).

Stage 1: Rozenite, szomolnokite, hexahydrite, and halotriquite (secondary sulfates), which were formed by the progress of oxidation and dehydration, were identified in both tailings [36]. The scarcity of melanterite and the presence of minerals that-according to the model of genetic evolution-are subsequent to this indicates that melanterite was probably formed, but it disappeared by continuous action of the same processes forming rozenite, which is the secondary hydrated sulfate that is more common in efflorescences of Xochula and Remedios tailings.

Stage 2: The second stage of minerals in the analyzed tailings are represented by the presence of copiapite and coquimbite (tertiary sulfate minerals), which are generated by the oxidation-dehydration of the minerals of the first stage. However, a mixture of minerals of both stages is observed in general; this may be the result of only a part of the minerals in the first stage having been altered, or that-within the same sample — these processes were acting simultaneously, leading to a stepped sequence of alteration. 


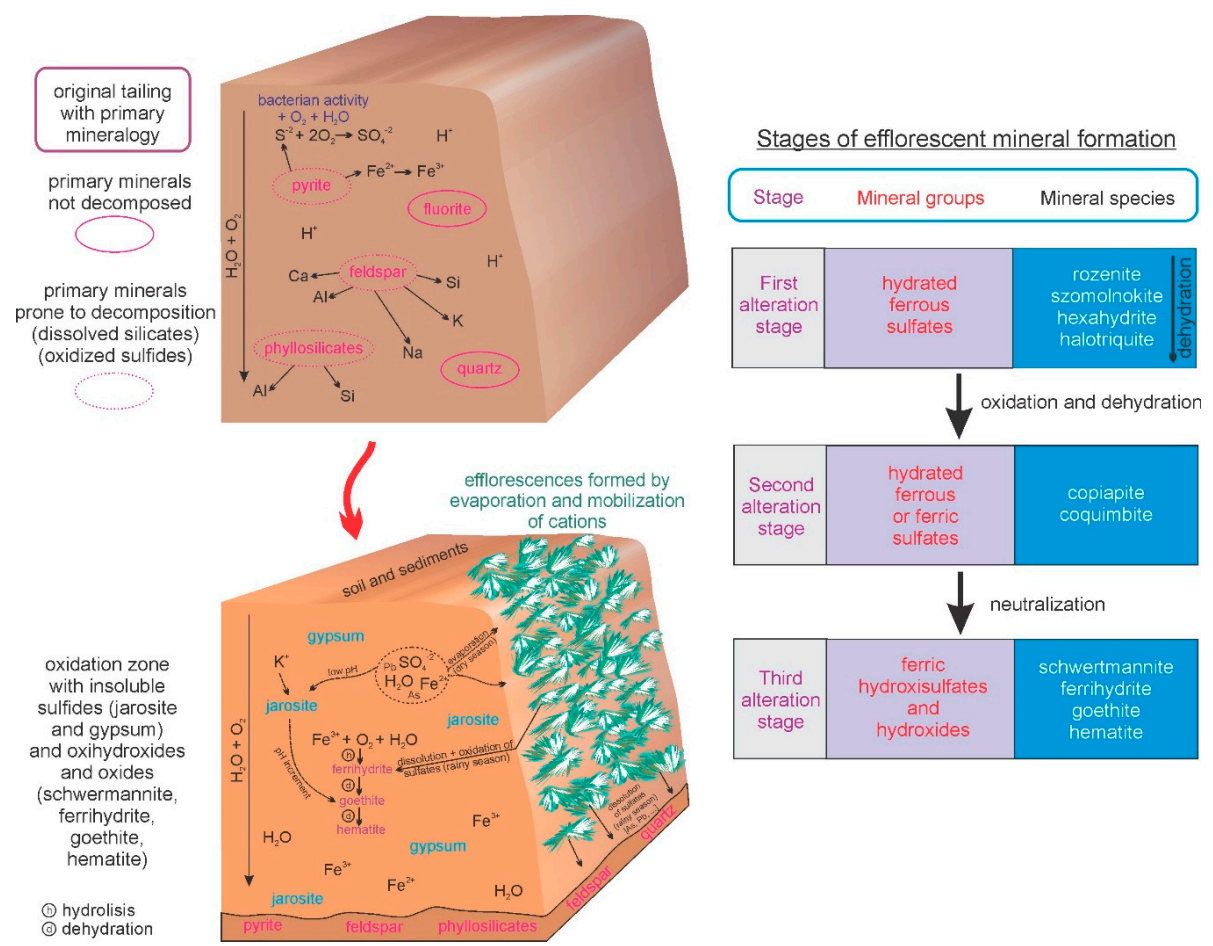

Figure 12. Stages of mineral (sulfates and oxides) precipitation formed mainly by oxidation, hydration, and evaporation.

Stage 3: The third stage of pyrite alteration in these tailings is represented by the presence of schwertmannite and ferrihydrite. Although they were identified in the studied sites, these minerals are found only in small amounts. This shortage is because they represent the last stage of alteration in which more stable minerals (goethite and hematite) are generated and there is still the generation of acidity in the deposits. The appearance of schwertmannite and ferrihydrite showcases the depletion of sources of acidity, according to [34].

According to [8], the efflorescences are a result of the consumption of the neutralization potential of the gangue minerals. The leached that determined the formation of efflorescent minerals is considered the final step in the evolution of the acid drainage system; at this point, it is too late for preventive actions, and only remediation tools can be applied (soil compactation, seal with clay, covers with sludge, dry covers, etc.) to avoid more affectations in the ecosystems [47]. For the Remedios and Xochula tailings, since they are small waste deposits, harvesting the efflorescences before the rainy season would reduce the risk of surface water contamination.

\section{Conclusions}

Xochula and Remedios tailings were both exposed to weathering for more than 50 years, developing a thick oxidation zone with jarosite as a predominant mineral and abundant efflorescent salts (secondary and tertiary soluble hydrated iron sulfates) in the borderline surface and lateral parts, where runoff water flows. As a result of this distribution, the removal of the efflorescences before the rainy season starts is a good alternative to avoid contamination of the water or air. Similarly to other efflorescences studied around the world, three paragenetic stages of the formation of efflorescent minerals were observed in both tailings. In the first stage, ferrous sulfates such as rozenite were formed; in the second one, ferrous and ferric sulfates (mainly copiapite and coquimbite) predominate; and in the final stage, iron hydroxides and oxides appear. The irregular distribution of non-oxidized pyrite in tailings as old as these can only be related to waste dumping in more recent times. The Remedios tailing is a younger and bigger deposit than Xochula, presenting greater mineralogical diversity but similar advanced mineralogical evolution. 
The SWIR technique proved to be very useful to quickly discriminate the samples with soluble sulfate. However, this technique did not allow for the individual sulfate minerals to be discriminated from each other, since the samples are mineralogically complex mixtures of minerals with very similar SWIR patterns. Only for the most abundant minerals ( $>25 \%$ in weight of the sample) was it possible to conduct their discrimination by SWIR by comparison with the literature spectra. The X-ray diffraction technique using the Rietveld refinement method turned out to be an ideal tool to characterize and quantify all the individual phases. Furthermore, statistical tools applied to the quantitative XRD results allowed us to establish the genetic relationship between the different mineralogical groups.

The geochemical data showed that efflorescent salts present concentrations of potentially toxic elements (especially $\mathrm{Zn}, \mathrm{Cu}$, As and $\mathrm{Pb}$ ) well above the values recommended by the World Health Organization and the country's legislation, demonstrating that the Xochula and Remedios tailings are still potentially harmful long after they were dumped. Tailings derived from ores similar to the ones in Taxco will not be mineralogically stabilized even after many decades of weathering, but their morphological exposure will progressively be confused with the landscape, making them a permanent source of contamination.

Supplementary Materials: The following are available online at http://www.mdpi.com/2075-163X/10/10/871/s1, Figure S1: Location of samples in Xochula (JH) and Remedios (JT) tailings., Table S1: Mineral phases identified and their relative abundance (\% weight) calculated with the Rietveld refinement method.

Author Contributions: Conceptualization, methodology, software, formal analysis, investigation, resources, and writing T.P.-P.; software, validation, writing, review, and editing J.S.; methodology, formal analysis A.G.C. All authors have read and agreed to the published version of the manuscript.

Funding: This research was partially funded by CONACYT: Laboratorios Nacionales, No. 299087.

Acknowledgments: We especially thank Augusto Rodríguez for his support during the SWIR analysis measurements and Mireia Lilit Solé Pi by the English revision of the manuscript. We also acknowledge the invitation of Rosa Maria Prol Ledesma to participate in the field geological work.

Conflicts of Interest: The authors declare no conflict of interest.

\section{References}

1. Agricola, G. De Re-Metallica; On Metallic Substances; Hoover, H.C.; Hoover, L.H., Translators; Dover Publications: Mineola, NY, USA, 1556; p. 638.

2. Karpenko, V.; Norris, J.A. Vitriol in the history of chemistry. Chem. Listy 2002, 96, 997-1005.

3. Nordstrom, D.K.; Alpers, C.N. Negative $\mathrm{pH}$, efflorescent mineralogy, and consequences for environmental restoration at the Iron Mountain Superfund site. California. Proc. Natl. Acad. Sci. USA 1999, 96, 3455-3462. [CrossRef] [PubMed]

4. Chicoș, M.M.; Damian, G.; Stumbea, D.; Buzgar, N.; Ungureanu, T.; Nica, V.; Iepure, G. Mineralogy and geochemistry of the tailings pond from Straja Valley (Suceava County, Romania). Factors affecting the mobility of the elements on the surface of the waste deposit. Carpathian J. Earth Environ. Sci. 2016, 11, 265-280.

5. Grover, B.P.C.; Johnson, R.H.; Billing, D.G.; Weiersbye, I.M.G.; Tutu, H. Mineralogy and geochemistry of efflorescent minerals on mine tailings and their potential impact on water chemistry. Environ. Sci. Pollut. Res. 2016, 23, 7338-7348. [CrossRef] [PubMed]

6. Hudson-Edwards, K.A.; Jamieson, H.E.; Lottermoser, B.G. Mine wastes: Past, present, future. Elements 2011, 7, 375-380. [CrossRef]

7. Hayes, S.M.; Root, R.A.; Perdrial, N.; Maier, R.M.; Chorover, J. Surficial weathering of iron sulfide mine tailings under semi-arid climate. Geochim. Cosmochim. Acta 2014, 141, 240-257. [CrossRef]

8. Dold, B. Evolution of Acid Mine Drainage Formation in Sulphidic Mine Tailings. Minerals 2014, 4, 621-641. [CrossRef]

9. Alpers, C.N.; Blowes, D.W.; Nordstrom, D.K.; Jambor, J.L. Secondary minerals and acid mine-water chemistry. In Environmental Geochemistry of Sulfide Mine-Wastes (Mineralogical Association of Canada Short Course Volumes); Jambor, J.L., Blowes, D.W., Eds.; Mineralogical Association of Canada: Quebec, QC, Canada, 1994; Volume 22, pp. 247-270. [CrossRef] 
10. Dold, B.; Fontboté, L. Element cycling and secondary mineralogy in porphyry copper tailings as a function of climate, primary mineralogy, and mineral processing. J. Geochem. Explor. 2001, 74, 3-55. [CrossRef]

11. Dold, B.; Fontboté, L. A mineralogical and geochemical study of element mobility in sulfide mine tailings of Fe oxide Cu-Au deposits from the Punta del Cobre belt, northern Chile. Chem. Geol. 2002, 189, 135-163. [CrossRef]

12. Buckby, T.; Black, S.; Coleman, M.L.; Hodson, M.E. Fe sulphate-rich evaporative mineral precipitates from Río Tinto, southwest Spain. Mineral. Mag. 2003, 67, 263-278. [CrossRef]

13. Hammarstrom, J.M.; Seal Ii, R.R.; Meier, A.L.; Kornfeld, J.M. Secondary sulfate minerals associated with acid drainage in the eastern US: Recycling of metals and acidity in surficial environments. Chem. Geol. 2005, 215, 407-431. [CrossRef]

14. Romero, A.; González, I.; Galán, E. The role of efflorescent sulfates in the storage of trace elements in stream waters polluted by acid mine-drainage: The case of Peña Del Hierro, southwestern Spain. Can. Mineral. 2006, 44, 1431-1446. [CrossRef]

15. Arranz-González, J.C.; Cala-Rivero, V.; Iribarren Campaña, I. Geochemistry and mineralogy of surface pyritic tailings impoundments at two mining sites of the Iberian Pyrite Belt (SW Spain). Environ. Earth Sci. 2011, 1-13. [CrossRef]

16. Jambor, J.L.; Nordstrom, D.K.; Alpers, C.N. Metal-sulfate salts from sulfide mineral oxidation. In Sulfate Minerals: Crystallography, Geochemistry, and Environmental Significance (Reviews in Mineralogy and Geochemistry); Alpers, C.N., Jambor, J.L., Nordstrom, D.K., Eds.; Mineralogical Society of America: Chantilly, VA, USA, 2000; Volume 40, pp. 303-350.

17. Nordstrom, D.K. Acid rock drainage and climate change. J. Geochem. Explor. 2009, 100, 97-104. [CrossRef]

18. Hyde, B.C.; King, P.I.; Dyar, M.D.; Spilde, M.N.; Ali, A.M.S. Methods to analyze metastable and microparticulate hydrated and hydrous iron sulfate minerals. Am. Mineral. 2011, 96, 1856-1869. [CrossRef]

19. Salas, G.P. Economic Geology, Mexico; Geological Society of America: Boulder, CO, USA, 1991; p. 453. ISBN 0-8137-5213-2.

20. Cambrubí, A.; Albinson, T. Epithermal deposits in México-Update of current knowledge, and an empirical reclassification. Geol. Soc. Am. Spec. Pap. 2007, 422, 1-40. [CrossRef]

21. Farfán-Panamá, J.L.; González-Partida, E.; Camprubí, A. Geología y mineralización del depósito epitermal polimetálico del distrito minero de Taxco, Guerrero, México, extended abstract. In Proceedings of the AIMMGM, XXX Convención Internacional de Minería, Acapulco, México, 16-19 October 2013.

22. IMSA. Geology and Ore Deposits of the Taxco Mining District; Inter. Report; IMSA: Guerrero, México, 1978; 40p.

23. Talavera-Mendoza, O.; Yta, M.; Moreno-Tovar, R.; Dótor-Almazán, A.; Flores-Mundo, N.; Duarte-Gutiérrez, C. Mineralogy and geochemistry of sulfide-bearing tailings from silver mines in the Taxco, Mexico area to evaluate their potential environmental impact. Geofis. Int. 2005, 44, 46-64.

24. López-Jiménez, R. Geological and Metallogenetic Features of the Manto Esperanza Vieja: Ag-Base-metal Epithermal Deposit of Taxco, Mexico. Master's Thesis, Universidad Complutense de Madrid, Madrid, España \& Universidad Nacional Autónoma de México, Querétaro, México, 2008; 98p.

25. Barrera, M. Geoquímica de metales pesados en los jales del Fraile municipio de Taxco, Guerrero, México. Master's Thesis, Instituto de Geofísica, UNAM, Querétaro, México, February 2001; 59p.

26. Armienta, M.A.; Talavera, O.; Morton, O.; Barrera, M. Geochemistry of Metals from Mine Tailings in Taxco, Mexico. Bull. Environ. Contam. Toxicol. 2003, 71, 387-393. [CrossRef]

27. Romero, F.M. Procesos Geoquímicos Que Controlan la Movilidad de Metales y Metaloides en Jales de Sulfuros Metálicos "El Fraile", Taxco Guerrero. Ph.D. Thesis, Instituto de Geofísica, UNAM, Querétaro, México, March 2004; 155p.

28. Talavera-Mendoza, O.; Armienta-Hernández, M.A.; García-Abundis, J.; Flores-Mundo, N. Geochemistry of leachates from the El Fraile sulfide tailings piles in Taxco, Guerrero, southern Mexico. Environ. Geochem. Health 2006, 28, 243-255. [CrossRef]

29. Romero, F.M.; Armienta, M.A.; González-Hernández, G. The solid-phase control on the mobility of potentially toxic elements in an abandoned lead/zinc mine tailings impoundment, Taxco, Mexico. Appl. Geochem. 2007, 22, 109-127. [CrossRef]

30. Liewig, N.; Clauer, N.; Sommer, F. Rb-Sr and K-Ar dating of clay diagenesis in Jurassic sandstone oil reservoirs, North Sea. Am. Assoc. Pet. Geol. Bull. 1987, 71, 1467-1474.

31. Jackson, M.L. Soil Chemical Analysis; Prentice Hall: Englewood Cliffs, NJ, USA, 1958; p. 498. 
32. Moore, D.M.; Reynolds, R.C., Jr. X-ray Diffraction and the Identification and Analysis of Clay Minerals, 2nd ed.; Oxford University Press: Oxford, UK, 1997; p. 378. [CrossRef]

33. Chukanov, N.V.; Chervonnyi, A.D. Infrared Spectroscopy of Minerals and Related Compounds; Springer: Berlin, Germany, 2016; p. 1116. ISBN 978-3-319-25347-3. [CrossRef]

34. Velasco, F.; Alvaro, A.; Suarez, S.; Herrero, J.M.; Yusta, I. Mapping Fe-bearing hydrated sulphate minerals with short wave infrared (SWIR) spectral analysis at San Miguel mine environment, Iberian Pyrite Belt (SW Spain). J. Geochem. Explor. 2005, 87, 45-72. [CrossRef]

35. Cloutis, E.A.; Hawthorne, F.C.; Mertzman, S.A.; Krenn, K.; Craig, M.A.; Marcino, D.; Methot, M.; Strong, J.; Mustard, J.F.; Blaney, D.L.; et al. Detection and discrimination of sulfate minerals using reflectance spectroscopy. Icarus 2006, 184, 121-157. [CrossRef]

36. Nordstrom, D.K. Aqueous pyrite oxidation and the consequent formation of secondary iron minerals. In Acid Sulfate Weathering; Kittrick, J.A., Fanning, D.S., Hossner, L.R., Eds.; Soil Science Society of America: Madison, WI, USA, 1982; Volume 10, pp. 37-56.

37. Rietveld, H. A profile refinement method for nuclear and magnetic structures. J. Appl. Crystallogr. 1969, 2, 65-71. [CrossRef]

38. Hawthorne, F.C.; Krivovichev, S.V.; Burns, P.C. The crystal chemistry of sulfate minerals. In Reviews in Mineralogy and Geochemistry; Sulfate Minerals: Crystallography, Geochemistry, and Environmental Significance; Alpers, C.N., Jambor, J.L., Nordstrom, D.K., Eds.; Mineralogical Society of America: Chantilly, VA, USA, 2000; Volume 40, pp. 1-101. [CrossRef]

39. Del Rio-Salas, R.; Ayala-Ramírez, Y.; Loredo-Portales, R.; Romero, F.; Molina-Freaner, F.; Minjarez-Osorio, C.; Pi-Puig, T.; Ochoa-Landín, L.; Moreno-Rodríguez, V. Mineralogy and Geochemistry of Rural Road Dust and Nearby Mine Tailings: A Case of Ignored Pollution Hazard from an Abandoned Mining Site in Semi-arid Zone. Nat. Resour. Res. 2019. [CrossRef]

40. Meza-Figueroa, D.; Maier, R.M.; de la O-Villanueva, M.; Gómez-Alvarez, A.; Moreno-Zazueta, A.; Rivera, J.; Campillo, A.; Grandlic, C.H.J.; Anaya, R.; Palafox-Reyes, J. The impact of unconfined mine tailings in residential areas from a mining town in a semi-arid environment: Nacozari, Sonora, Mexico. Chemosphere 2009, 77, 140-147. [CrossRef]

41. WHO (World Health Organization). Global Health Observatory Data Repository: International Health Regulations (2005) Monitoring Framework. Available online: https://apps.who.int/gho/data/node.main-eu. IHR?lang=en (accessed on 17 June 2020).

42. NORMA Oficial Mexicana, NOM. 141-SEMARNAT-2003. In Que Establece El Procedimiento Para Caracterizar Los Jales, así Como Las Especificaciones Y Criterios Para La Caracterización Y Preparación Del Sitio, Proyecto, Construcción, Operación Y Postoperación de Presas de Jales, Diario Oficial de La Federación; Estados Unidos Mexicanos-Secretaria de Medio Ambiente y Recursos Naturales: Mexico City, Mexico, 2004.

43. Jamieson, H.E.; Robinson, C.; Alpers, C.N.; McCleskey, R.B.; Nordstrom, D.K.; Peterson, R.C. Major and trace element composition of copiapite-group minerals and coexisting water from the Richmond mine, Iron Mountain, California. Chem. Geol. 2005, 215, 387-405. [CrossRef]

44. Escobar-Quiroz, I.N.; Villalobos-Peñalosa, M.; Pi-Puig, T.; Martín Romero, F.; Aguilar-Carrillo de Albornoz, J. Identification of jarosite and other major mineral Fe phases in acidic environments affected by mining-metallurgy using X-ray Absorption Spectroscopy: With special emphasis on the August 2014 Cananea acid spill. Rev. Mex. Cienc. Geol. 2019, 36, 229-241. [CrossRef]

45. Jamieson, H.E.; Walker, S.R.; Parsons, M.B. Mineralogical characterization of mine waste. Appl. Geochem. 2015, 57, 85-105. [CrossRef]

46. Shahroz Khan, S.; Haq, F.; Hasan, F.; Saeed, K.; Ullah, R. Growth and Biochemical Activities of Acidithiobacillus thiooxidans Collected from Black Shale. J. Microbiol. Res. 2012, 2, 78-83. [CrossRef]

47. Pozo-Antonio, S. Techniques to correct and prevent acid mining drainage. DYNA (Medellín, Colombia) 2014, 81, 73-80. [CrossRef]

(C) 2020 by the authors. Licensee MDPI, Basel, Switzerland. This article is an open access article distributed under the terms and conditions of the Creative Commons Attribution (CC BY) license (http://creativecommons.org/licenses/by/4.0/). 